$1-1-2012$

\title{
Accounting for Time: A Relative-Interest Approach to the Division of Equity in Hybrid-Property Homes Upon Divorce
}

Lisa Milot

University of Georgia School of Law, Imilot@uga.edu

p bepress $S S R N$

\section{Repository Citation}

Lisa Milot, Accounting for Time: A Relative-Interest Approach to the Division of Equity in Hybrid-Property Homes Upon Divorce, 100 Ky. L.J. 585 (2012),

Available at: https://digitalcommons.law.uga.edu/fac_artchop/947

This Article is brought to you for free and open access by the Faculty Scholarship at Digital Commons @ University of Georgia School of Law. It has been accepted for inclusion in Scholarly Works by an authorized administrator of Digital Commons @ University of Georgia School of Law. Please share how you have benefited from this access For more information, please contact tstriepe@uga.edu. 


\title{
Accounting for Time: A Relative-Interest Approach to the Division of Equity in Hybrid-Property Homes Upon Divorce
}

\author{
Lisa Milot ${ }^{\mathrm{I}}$
}

\section{INTRODUCTION}

GEw Americans own any asset more valuable than a home. ApproximateF ly two-thirds of families own the home in which they live ${ }^{2}$ and home equity represents nearly half of the typical household's net worth. ${ }^{3}$ Divorce is only slightly less common than homeownership-in 2009, for example, there were almost half as many divorces nationally as there were marriages. ${ }^{4}$ Thus, in hundreds of thousands of divorce proceedings each year, equity in marital homes must be divided between the spouses.

In making this division, most courts begin by classifying each piece of property owned by a divorcing couple as either "separate" or "marital" property. ${ }^{5}$ Except in rare cases, courts simply allocate to each spouse his or her separate property. In contrast, marital property is generally divided

I Assistant Professor at the University of Georgia School of Law. I thank Dan T. Coenen, Joanna Shepherd Bailey, Louise E. Graham, Andrea Dennis, Paul Heald, Paul Kurtz, Jim Smith, and the many others who were generous with their time, support, guidance, and comments in preparation of this Article. In addition, I thank Karen Bemis, Erica Gilbert-Wason, and Amanda Reed for their invaluable research assistance.

2 See Nat'l Assoc. of Realtors, Profile of Home Buyers and Sellers 2010 i 2 (2010); see also Robert R. Callis \& Melissa Kresin, U.S. Dep't of Commerce, U.S. Census Bureau News, Residential Vacancies and Homeownership in the Second Quarter 5 (20 I I), available at http://www.census.gov/hhes/www/housing/hvs/qtr2 I I/files/q2 I I press.pdf (reporting quarterly homeownership rates in 2010 of $67.1 \%, 66.9 \%, 66.9 \%$, and $66.5 \%$ ).

3 See Brian K. Bucks et al., Changes in U.S. Family Finances from 2004 to 2007: Evidence from the Survey of Consumer Finances, 95 FED. Reserve Bulletin AI, A33 (2009), available at http://www.federalreserve.gov/pubs/bulletin/2009/pdf/scfo9.pdf (showing that house values as a percent of all assets of a household ranged between $44.5 \%$ and $5 \mathrm{I} .8 \%$ for families below the ninety percent percentile of income in 2007).

4 U.S. Dep't. of Health \& Human Servs., Births, Marriages, Divorces, and Deaths: Provisional Data for 2009, in Nat'L Vital Statistics Report, Aug. 27, 20 I0, at I, available at http:// www.cdc.gov/nchs/data/nvsr/nvsr58/nvsr58_25.pdf (showing 6.8 marriages and 3.4 divorces per thousand Americans).

5 For a discussion of the distinction between separate and marital property, see infra notes $2 \mathrm{I}-24$ and accompanying text. 
based on "equitable principles." Simple in theory, this initial division often proves complex in practice in part because some property has both separate and marital components. Courts must divide the value of this "hybrid" property between the separate and marital estates before distributing it. ${ }^{7}$ Many homes are hybrid property for a simple reason: they are initially purchased prior to marriage, ${ }^{8}$ but significant mortgage payments are made after the marriage occurs. The issue courts face is how to divide the equity in a home brought into a marriage, but paid for in part during the course of the marriage.

Consider a house sold in December 1997 for $\$ 250,000 .{ }^{9}$ Harry, the purchaser, makes a $\$ 50,000$ down payment and takes out a $\$ 200,000$ mortgage. By the time he marries Sally two years later, Harry has paid off $\$ 5000$ of the mortgage and the house is worth $\$ 280,000$, so that his net equity in the home at the time of marriage is $\$ 85,000$ and the outstanding mortgage balance is $\$ 195,000 .{ }^{10}$ During their marriage, Harry and Sally make monthly mortgage payments that reduce the principal of the loan by $\$ 20,000$; they also make a special lump sum payment of $\$ 65,000$ at the end of $2005 .{ }^{11}$ After these payments, the loan balance is $\$ 110,000 .{ }^{12}$ When the marriage dissolves in June 2006 , the home is worth $\$ 730,000$, with a net equity value of $\$ 620,000 .{ }^{13}$ Who should get what part of this value?

6 See infra note 33 .

7 See infra Part I.A for a discussion of hybrid property.

8 See Nat'l Assoc. of Realtors, Profile of Home Buyers and Sellers 9, 70 (2010) (finding that thirty-two percent of homebuyers in 2010 were unmarried and that eighty-nine percent of them financed the purchase at least in part). The issue of dividing the equity in homes that are hybrid property is a growing issue: ten years ago unmarried individuals comprised only twenty-two percent of home purchasers. Id. at 9 .

9 See Appendix A for precise data and calculations; all numbers in this discussion have been rounded for convenience.

Io The conventional financing approach to purchasing a home involves a twenty percent down payment and a thirty-year fully-amortized mortgage. Matthew Chambers et al., Accounting for Changes in the Homeownership Rate 23 (Fed. Reserve Bank of Atlanta, Working Paper No. 2 I, 2007).

I I The approach—and problem—would be the same without the lump sum payment, however this Article assumes the payment to more clearly show the central issue at hand.

I2 The initial principal of the mortgage was $\$ 200,000$. This has been reduced by $\$ 5000$ (from the premarital mortgage payments), $\$ 20,000$ (from the marital mortgage payments), and $\$ 65,000$ (from the lump sum principal payment).

I3 A home's net equity value is equal to its fair market value reduced by any outstanding mortgage or other secured loan. Thus, $\$ 730,000-\$ \mathrm{II}, 000=\$ 620,000$. While high, this level of appreciation is based on actual appreciation in the Washington, D.C. metro area in the early 2000s. The problem remains even where the levels of appreciation are lower. See Press Release, Fed. Hous. Fin. Agency, House Prices Fall Modestly in the Fourth Quarter 5 I-52 (2010), available at http://www.fhfa.gov/webfiles/I5452/finalHPI225I o.pdf (showing the average appreciation of a $\$ \mathrm{I} 00,000$ home in Washington, D.C. for each quarter from I99I through 2009). 
Lawmakers have developed a variety of approaches for dealing with this problem. A few states give Harry's investment a strong priority; thus, the marital estate is reimbursed only for the $\$ 85,000$ it contributed to the home's value while Harry receives the full remaining $\$ 535,000 .{ }^{14} \mathrm{~A}$ small number of states strictly favor the marital interest. Indeed, some even classify the entire $\$ 620,000$ as marital property. ${ }^{15}$

Most states opt for a more balanced approach. They purport to divide the available equity based on economic principles, with the stated goal of providing a "proportionate and fair return" on investment ${ }^{16}$ in the home to both the separate and marital estates. In particular, courts in many states would divide the equity in our theoretical case equally between the separate and marital estates on the theory that Harry, individually, and Harry and Sally, jointly, have each contributed an equal amount $-\$ 85,000-$ towards the home's value. ${ }^{17}$ In this view, classifying one-half of the equity as separate and one-half as marital produces the right result because it allocates the value in a way that is proportionate to the relative investments in the home.

But is it actually proportionate? Harry's individual contributions to the home's value were made years prior to the bulk of the marital contributions. In fact, the separate estate was fully invested by the time of the

I4 This is the "inception of title" or "lien" approach, discussed infra note 37. In some cases, a flat interest rate is accorded the investment so that there is some rate of return allowed, but it is not based on the actual appreciation of the asset's value during the period of ownership.

I 5 This occurs where the separate property is deemed to be transmuted into marital property. See infra notes $26-27 \& 30$ and accompanying text. In some cases, commentators have suggested that separate property be transmuted into marital property over time. See infra notes 28-29 and accompanying text for a discussion of these proposals.

I6 See, e.g., Maddox v. Maddox, 604 S.E.2d 784, 786 (Ga. 2004) (stating that both the separate and marital estates should "receive[] a proportionate and fair return on their investment" in hybrid property); In re Marriage of Herr, 705 S.W.2d 6I9, 624 (Mo. Ct. App. I986) (same); Wade v. Wade, 325 S.E.2d 260, 269 (N.C. Ct. App. I 985) (same); and Smoot v. Smoot, 4 Va. Cir. I82, I90 (Va. Cir. Ct. I984) (same).

See also In re Marriage of Moore, 61 8 P.2d 208, 2 Io (Cal. I980) (developing a pro tanto interest rule in which increases in the value of property with both separate and community interests are shared proportionately); Hall v. Hall, 462 A.2d I I 79, I I8I (Me. I983) ("[T]he marital estate is entitled to a proportionate return on its investment. . . The marital and non-marital estates have each made investments from which they are entitled to the full benefit and return.”); Hoffman v. Hoffman, 6 4 A.2d 988, 993 (Md. Ct. Spec. App. I992) (“[T] he spouse contributing nonmarital funds [to hybrid property] is entitled to a fair and equitable return on his or her investment."); Sally Burnett Sharp, The Partnership Ideal: The Development of Equitable Distribution in North Carolina, 65 N.C. L. Rev. I95, 2 I 5-I6 (1987) (noting that, with respect to hybrid property, North Carolina law "mandates a fair and proportionate 'return on investment' for each estate").

I7 Harry's individual contribution is the home's net equity upon marriage $(\$ 85,000)$, comprised of his down payment, his premarital mortgage principal payments, and the premarital appreciation. The couple's marital contributions are also $\$ 85,000$, due to the $\$ 20,000$ in monthly mortgage principal payments and the $\$ 65,000$ lump sum payment. 
marriage, whereas the most substantial part of the marital investmentthe lump sum payment-was not made until six years later. The standard formula, however, ignores this difference in timing. No rational investor would choose to invest in an asset, foregoing other profitable uses of that money in the meantime, if he knew that he would receive exactly the same return if he waited six years to invest the same amount in the same asset. Yet that is exactly what courts choose for Harry: in this context, an investment is an investment, regardless of when it is made.

The practical consequence of this approach is deeply troubling. In effect, the accumulated appreciation in the couple's home is allocated as if the marital estate held a fifty percent interest for the duration of the marriage, even though this is obviously not the case. Thus all gains in the earliest years of the marriage are allocated equally between the estates despite the fact that, at the time, each estate held very unequal equity interests in the property. In a related point, the prevailing approach fails to account for the discontinuous nature of home appreciation. This problem arises because, unlike an annuity or other fixed return investment, a home's rate of return is not constant. As a result, actual gain should be allocated between the separate and marital estates each time the estates' relative interests in the hybrid property change. Otherwise, serious inequities result because each investment's risk becomes disconnected from its returns.

The example of Harry and Sally reveals the wide gulf that exists between what courts in divorce cases profess to be doing and what they are actually doing with respect to the division of equity in hybrid-property homes. Contrary to their pronouncements, courts are not dividing home equity so as to provide a proportionate and fair return to each of the separate and marital estates. ${ }^{18}$ Instead, they are dividing it in a crude way that ignores economic realities in making substantial and hidden transfers of wealth from the separate to the marital estate.

Part I of this Article discusses the primary ways in which courts classify the equity held by all couples in hybrid property. It shows how the equity in a home like Harry and Sally's would be divided between the separate and marital estates under existing legal formulas. It also argues that the resulting allocations of appreciation are unsound because they fail to take proper account of critical timing considerations.

I 8 This problem similarly occurs in the case of other assets in which investments are made over time, such as retirement plan assets, and those that are debt-financed, such as many small businesses and cars. The valuation of retirement plan assets is discussed infra Part II.A. For an overview and critique of the allocation of the value of family-owned businesses, see generally William A. Reppy, Jr., Apportioning Business Profits Generated by Spousal Labor and Capital Owned over Time by Shifting Fractional Shares of the Separate and Community/Marital Estates, 3 I FAM. L.Q. 63 ( I 997). The problems presented by hybrid-property automobiles are largely the same as those presented by hybrid-property homes, although the scale of the problem is much smaller given the difference in typical value between cars and houses. 
An economically sensible approach to this problem is developed in Part II. Here the argument is made that courts can and should take a time-sensitive approach of how to divide the equity in hybrid-property homes. In particular, Part II demonstrates the soundness of this "relative-interest" approach by analogizing it to the relative-value approach used in dividing the value of hybrid-property defined-contribution retirement plan accounts upon divorce.

Part III responds to potential critiques of the relative-interest approach based on its increased adjudicative complexity. This Part concludes that, while this approach involves more complexity than now-prevalent formulas, it is significantly fairer, attuned to economic realities, and not unduly difficult to administer.

Part IV discusses important implications of the preceding analysis. It argues that current approaches to the allocation of equity in hybrid-property homes represent a misalignment of legal rhetoric and legal reality. This misalignment may reflect efforts by courts to provide themselves with greater flexibility in allocating wealth between spouses. It may be the product of technological and informational constraints that existed in an earlier time. Or it may be the result of a general preference for numerical simplicity over computational complexity in the law. Whatever the reason, current approaches to allocating equity in hybrid-property homes produce substantial transfers of wealth that courts need to openly recognize and carefully address. Of particular importance, this Part highlights how, as technology develops, existing rules must be reassessed to ensure that they remain properly structured to address the goals they profess to advance.

\section{Classifying Assets: Separate, Marital, or Both?}

In every U.S. state, upon marital dissolution ${ }^{19}$ a couple's property must be classified as either the separate property of one spouse or as the marital property of the couple. ${ }^{20}$ Marital property generally includes all property

I9 Depending on the jurisdiction, the relevant date for dividing the assets is either the couple's date of separation or date of divorce. Compare N.C. Gen. Stat. § 50-2 I(b) (2009) (assets are to be valued as of date of separation), with Cotter v. Cotter, 473 A.2d 970, 974 (Md. Ct. Spec. App. 1984) (interpreting the Maryland code to require the dissolution date as the date of divorce). For convenience, I refer to the date on which property is classified and divided between the divorcing spouses as the "dissolution date" in this Article, but the exact meaning of the term is based on the relevant state's law.

20 For a description of what is typically considered marital versus separate property, see Principles of the Law of Family Dissolution: Analysis \& Recommendations $\$ 4.03$ (2000) [hereinafter Law of Family Dissolution]. Fifteen states formally allow equitable distribution of all property, which would imply that these states make no distinction between separate and marital property. See Brett R. Turner, Unlikely Partners: The Marital Home and the Concept of Separate Property, 20 J. Am. Acad. Matrimonial Law. 69, 7 I n.8 (2006). In practice, however, even these states begin by presumptively allocating separate property to the spouse in whose name it is titled. Ira Mark Ellman et al., Family law: Cases, Text, Problems 
acquire by either spouse during the marriage, regardless of how it is titled. ${ }^{21}$ Separate property includes gifts, bequests, and inheritances specifically given to only one spouse during the marriage, as well as any property acquired before the marriage took place. ${ }^{22}$ Property clearly traceable to a nonmarital source-for example, cash from the sale of a car that was owned prior to marriage-is separate property. ${ }^{23}$ Passive appreciation-that is, appreciation attributable to market forces such as inflation-is generally classified as separate property if the appreciated property is itself separate property, and marital if the underlying property is marital property. ${ }^{24}$

A basic principle of family law is that marriage changes spouses' relationship to each other, to their assets, and to the law. ${ }^{25}$ However, assets that predate the marriage, or are outside the marriage—separate property—are

339-4I, 354 (5th ed. 2010). Only where there is a strong reason to override this division, such as in a long-term marriage where the respective financial position of one spouse would be greatly disadvantaged relative to that of the other spouse, is separate property allocated to the non-titled spouse. $I d$. at 354 . As a result, even in these jurisdictions it proves necessary to distinguish between separate and marital property. In community property jurisdictions, the distinction is between separate property and community property, but the classification process is the same. Law of Family Dissolution, supra, $\S 4.02 \mathrm{cmt}$. a.

2 I See, e.g., Md. Code Ann., Fam. Law § 8-20I(e) (LexisNexis 2006) (defining marital property); Law of Family Dissolution, supra note 20, $\$ 4.03$ (same).

22 In addition, the spouses can agree that otherwise marital property be classified as separate or the reverse. See, e.g., § 8-20I(e)(3) (listing property that is not included as marital property); LaW of Family Dissolution, supra note 20, § 4.03(2) (explaining that marital property does not include, inter alia, gifts, bequests, and inheritances).

23 See, e.g., § 8-20I(e)(3)(iv) (excluding specifically property "directly traceable" to nonmarital property from the definition of marital property); Law of Family Dissolution, supra note $20, \S 4.03(3)$ ("Property received in exchange for separate property is separate property even if acquired during marriage.").

24 See, e.g., VA. Code Ann. § 20-I07.3(A)(I) (Supp. 20 I I) ("The increase in value of separate property during the marriage is separate property, unless marital property or the personal efforts of either party have contributed to such increases and then only to the extent of the increases in value attributable to such contributions."); Law of Family Dissolution, supra note $20, \S 4.04$ (characterizing appreciation and income of separate property during the marriage as separate property so long as they are not the result of either spouse's labor and the underlying asset has not been transmuted into marital property). This would include, for example, income from securities bought prior to marriage. See generally Brett R. Turner, The Benefits of Prosperity: Classification and Division of the Appreciation of Separate Property (Part 2), 5 Divorce Litig. I09 (I993) (providing a thorough overview of state law approaches to classifying passive appreciation).

25 See, e.g., Law of Family Dissolution, supra note $20, \S 4.03 \mathrm{cmt}$. a (emphasis in original) (explaining that "the law of nearly every state reflects the view that marriage alone is sufficient to support a spousal claim of shared ownership at divorce to property earned by marital labor . ...”); Ellen Kandoian, Cohabitation, Common Law Marriage, and the Possibility of a Shared Moral Life, 75 GEo. L.J. I 829, I 833 ( I987) (explaining that family law "views marriage as defining and modifying, in an essential way, the identities of the marriage partners.... The terms and conditions of marriage flow from the status, not from private negotiation."); 3 ArNOLD H. RUTKIN et al., Family Law \& Practice $\$ 37.0$ I (20 I I) ("The property rights of two individuals usually are significantly altered when they are married."). 
only transformed into marital property if the property owner so intends ${ }^{26}$ or, in unusual circumstances, if a statutes specifies this treatment. ${ }^{27}$ While some commentators have proposed transmuting separate property into marital, either due to joint use ${ }^{28}$ or because of the passage of time, ${ }^{29}$ state legislatures have not embraced this approach. Rather, they have transformed separate property into marital property only when the two forms have become so blended with each other that tracing the relative shares is impractical. $^{30}$

Even when gradual transmutation of separate property into marital property has been proposed, the respective separate and marital components must still be identified prior to shifting some portion of the separate property to the marital estate. ${ }^{31}$

As a result, property classified as separate generally remains the property of the spouse who acquired it upon divorce. ${ }^{32}$ Property classified as mari-

26 See, e.g., Carr v. Carr, ${ }_{52}$ P.3d 45o, 454 (Alaska 2007) (explaining that intent is required to transform separate property into marital property).

27 See, e.g., § 20-I07.3(A)(3) (describing circumstances under which separate property will be transmuted into marital property).

28 See, e.g., Carolyn J. Frantz \& Hanoch Dagan, Properties of Marriage, i04 Colum. L. Rev. 75 , I 6 (2004) ("[T]here is one circumstance where property should be transmuted regardless of intent-when items are used during marriage.").

29 See, e.g., Law of Family Dissolution, supra note $20, \S 4.12 \& \mathrm{cmt}$. a (providing for separate property owned by a spouse in a long-term marriage to be transmuted in part to marital property, with the exact portion determined based on the length of the marriage); Shari Motro, Labor, Luck, and Love: Reconsidering the Sanctity of Separate Property, 102 Nw. U. L. REv. I623, I652-53 (2008) (arguing that an increasing percent of separate property should be included in the marital estate based on the time period during marriage for which the asset is owned divided by the owner spouse's remaining life expectancy).

Analogously, the 1993 Revision of the Uniform Probate Code gradually increased a surviving spouse's elective share of a decedent's estate based on the marriage's duration, includes the survivor's own assets in the estate subject to her elective share, and applies an increasing percent of the survivor's separate assets in satisfaction of the share. Unif. Probate Code $\S 2-202$ (a) (amended 1993) (defining "Elective Share Amount"); id. § 2-207(a) (defining "Included Property"); id. § 2-209(a)(2) (defining "Sources from Which Elective Share Payable").

30 See, e.g., $\$ 20-107.3(\mathrm{~A})(3)(\mathrm{d})$ ("When marital property and separate property are commingled by contributing one category of property to another, resulting in the loss of identity of the contributed property, the classification of the contributed property shall be transmuted to the category of property receiving the contribution. However, to the extent the contributed property is retraceable by a preponderance of the evidence and was not a gift, such contributed property shall retain its original classification."); see also LaW of Family Dissolution, supra note $20, \S 4.03 \mathrm{cmt}$. c.

3I Under Motro's model, for example, the classifications of marital and separate property remain significant, though the treatment of each would vary from current practice: "Separate property spent during marriage would be presumptively marital.... Whatever was left would simply be separate." Motro, supra note 29, at i656; see also Law of Family Dissolution, supra note $20, \S 4.03$ (defining separate and marital property).

32 See Law of Family Dissolution, supra note 20, § 4. I I \& cmt.; see also supra note 20 (discussing jurisdictions subjecting all assets to equitable division). 
tal is subject to "equitable distribution," and is generally divided between the spouses based on equitable factors. ${ }^{33}$ The key point is this: While family law generally focuses on equitable considerations in distributing marital property, it focuses on objective considerations in determining whether property is separate or marital in the first instance-that is, when and how the property was acquired. ${ }^{34}$

\section{A. The Classification of Hybrid Property}

The classification of property as separate or marital is not an all-ornothing exercise. ${ }^{35}$ Instead, most jurisdictions recognize that both separate and marital interests can coexist in property. This situation arises, for example, when a couple acquires an asset using a combination of separate and marital funds.

Property that contains both separate and marital interests is labeled "hybrid property." ${ }^{6}$ While some assets become classified as hybrid property because they are, from the outset, purchased with a combination of funds, others are so classified because they are purchased over time, generally with early payments made from separate funds and later payments made from marital funds. Regardless of how the hybrid property comes about, upon divorce its value must be divided between the separate and marital estates before it can be distributed.

To classify the equity in hybrid property on divorce, most jurisdictions focus on the "source of funds" used to acquire the property. ${ }^{37}$ Once the

33 See Rutkin ET AL., supra note 25 , at $\$ 37.0$ I ("The equitable distribution theory . . . is now utilized in some form by all jurisdictions in the United States."). Community property states and twelve common law jurisdictions require an equal, rather than equitable, division of marital assets. See Laura A. Rosenbury, Two Ways to End a Marriage: Divorce or Death, 2005 UTAн L. Rev. I 227, I 236 n.3 I (2005). In the other U.S. jurisdictions, marital property may, and often is, divided unequally between the divorcing spouses based on equitable factors. These factors may include consideration of the relative contributions to the acquisition of the property by the spouses, as well as each spouse's separate property, job market skills, age, health, and fault. $I d$. at 1237 .

34 See Law of Family Dissolution, supra note 20, § 4.03; i Brett R. Turner, Equitable Distribution of Property $§ 5: 28$ (Supp. 20io) [hereinafter Turner, Equitable DistribuTION].

35 See Turner, Equitable Distribution, supra note 34 , § 6:84; see also § 20-I07.3(A)(3) (describing instances in which a court should "classify property as part marital property and part separate property").

36 Turner, Equitable Distribution, supra note 34 , $\$ 6: 84$ (discussing how a single property can be classified as both marital and separate property and would therefore be considered "hybrid property").

37 See Motro, supra note 29, at I64I. Alternatively, most community property states use an "inception of title" approach, in which the home is deemed to be separate property with the marital estate only entitled to reimbursement of amounts contributed to its value (and possibly a market rate of interest). See id. at I643 n.76; see also Fisher v. Fisher, 383 P.2d 840, 842-43 (Idaho I963) (explaining and employing the inception of title approach); Rogers v. 
respective separate and marital contributions are calculated, the value of the property is divided proportionately between the estates based on the portion of the total funds provided by each. ${ }^{38}$ States have developed various formulas to divide the equity in hybrid-property homes between the separate and marital estates. ${ }^{39}$ Under each of them, the separate and marital contributions to the home's value are identified. Only amounts spent that add to the home's equity count as a contribution; as a general matter these additions to equity include any initial down payment, later mortgage principal payments, and the value added to the property by any improvements. ${ }^{40}$ The goal is to develop a formula that ensures that both estates receive a proportionate and fair return on their investments. ${ }^{41}$

\section{B. Dividing the Equity in a Hybrid-Property Home}

The formula most often used by courts in determining the separate and marital interests in a hybrid-property home in common law jurisdictions was developed by the Kentucky Court of Appeals in Brandenburg v.

Rogers, 754 S.W.2d 236, 239 (Tex. Ct. App. 1988) (explaining same). In other instances, the combination of nonmarital and marital property will serve to transmute the separate interest so that the property's entire value is classified as marital property. See, e.g., Motro, supra note 29, at I64I (discussing the transmutation approach).

38 See, e.g., Brett R. Turner, Virginia's Equitable Distribution Law: Active Appreciation and the Source of Funds Rule, 47 WASH. \& LEE L. Rev. 879, 890 ( I990) (explaining "[t]he source of funds rule provides that when property is acquired with marital and separate funds, the ratio between the marital and separate interests is the ratio between the marital and separate contributions").

39 See, e.g., Thomas v. Thomas, 377 S.E.2d 666, 669-70 (Ga. 1989), discussed infra notes7 I-72 and accompanying text; Hoffman v. Hoffman, 6 I 4 A.2d 988, 993-94 (Md. Ct. Spec. App. I992), discussed infra notes 75-76 and accompanying text; and Schmitz v. Schmitz, 309 N.W.2d 748, 750 (Minn. I98I), discussed infra notes 73-74 and accompanying text.

40 See, e.g., Brandenburg v. Brandenburg, 617 S.W.2d 87I, 872-73 (Ky. Ct. App. I98I) (including premarital principal payments as nonmarital contributions and post-marriage ones as marital, and defining marital contribution to include the value of all improvements made to the property after marriage from funds other than nonmarital funds); Schmitz, 309 N.W.2d at 749 (including wife's down payment as a nonmarital contribution). The cost of improvements above the value they add, interest paid on a mortgage, amounts spent on maintenance, personal labor expended on or within the home, and payment of taxes and insurance are not considered contributions under this approach. See, e.g., Hart v. Hart, 497 S.E.2d 496, 505 (Va. Ct. App. I998) ("It is the value the improvements add to that property, not their cost, that is the proper consideration ...."); Brandenburg, 6 7 S.W.2d at 873 (holding that non-monetary contributions are not to be considered in determining marital and separate interests in the property). See generally Turner, Equitable Distribution, supra note 34, § 5:26 (cataloguing payments included as contributions to a home's value, and those excluded).

4I See supra note I6 and accompanying text. Of course, a home is more than an investment. In the case of a primary home, it provides shelter and it may also represent a form of consumption. However, in dividing the equity in a hybrid-property home between the separate and marital estates, courts focus on the value of the home as an asset. 
Brandenburg. ${ }^{42}$ This formula divides the nonmarital contributions, including premarital appreciation, to the home's value by the total contributions to its value, and then multiplies the resulting fraction by the home's net equity on the dissolution date. ${ }^{43}$ Conversely, the marital interest is equal to the marital contributions divided by the total contributions, multiplied by the net equity in the home on the dissolution date. ${ }^{44}$

In the case of Harry and Sally's home, ${ }^{45}$ the net equity on the date of marriage was $\$ 85,000{ }^{46}$ This amount consisted of Harry's $\$ 50,000$ down payment, $\$ 5000$ in premarital mortgage principal payments, and $\$ 30,000$ in premarital appreciation. Harry made no later nonmarital contributions, so the numerator for determining Harry's separate interest under Brandenburg is $\$ 85,000$. Likewise, the marital contributions total $\$ 85,000$ and consist of the couple's $\$ 20,000$ in monthly mortgage principal payments as well as the additional $\$ 65,000$ payment. The equity on the dissolution date is $\$ 620,000 .{ }^{47}$ Under the Brandenburg formula, Harry's separate interest is equal to the value of his separate contributions $(\$ 85,000)$ divided by the sum of the separate and marital contributions $(\$ 170,000)$. Thus, one-half of the home's net equity $(\$ 310,000)$ is classified as separate property since Harry's separate contributions were one-half of the total contributions. ${ }^{48}$ The marital interest would also be $\$ 310,000$ since the couple jointly provided the other one-half of the contributions. ${ }^{49}$

42 Brandenburg, 6I 7 S.W.2d 87I. For a general discussion of Brandenburg in the context of Kentucky jurisprudence on property division, see Louise Everett Graham, Using Formulas to Separate Marital and Nonmarital Property: A Policy Oriented Approach to the Division of Appreciated Property Upon Divorce, 73 Ky. L.J. 4I, 44-45 \& 69-70 (I984).

43 Brandenburg, 6 I 7 S.W.2d at 872 . In algebraic terms, the Brandenburg court provides that $\mathrm{nmc} / \mathrm{tc} \times \mathrm{e}=$ nonmarital property, where " $\mathrm{nmc}$ " is the nonmarital contribution, comprised of "the equity in the property at the time of marriage, plus any amount expended after marriage by either spouse from traceable nonmarital funds in the reduction of mortgage principal, and/or the value of improvements made to the property from such nonmarital funds," "tc" is the total contribution from marital and nonmarital funds, and " $\mathrm{e}$ " is the net equity at the time of dissolution of the marriage or, if sold at an earlier date, the time of sale. Id.

44 The Brandenburg court utilizes the formula $\mathrm{mc} / \mathrm{tc} \times \mathrm{e}=$ marital property, where "mc" is the marital contribution, and is equal to the sum of the "amount expended after marriage from other than nonmarital funds in the reduction of mortgage principal, plus the value of all improvements made to the property after marriage from other than nonmarital funds." Id.

45 See supra Introduction for the hypothesized facts.

46 The home's value on the date of marriage was $\$ 280$, o00 and the outstanding mortgage was $\$ 195,000$, yielding a net equity of $\$ 280,000-\$ 195,000$, or $\$ 85,000$.

47 The home's fair market value is $\$ 730$, 000 and the outstanding mortgage is $\$ 110,000$, yielding a net equity calculation of: $\$ 730,000-\$ 1 \mathrm{I} 0,000=\$ 620,000$.

$48 \frac{\$ 85,000 \text { separate contributions }}{\$ 170,000} \times \$ 620,000$ net equity $=\$ 310,000$ separate equity $\$$ I 70,000 total contributions

49 Because both the nonmarital and marital contributions are equal to $\$ 85$,000 in this example, the calculation of the marital interest is identical to that of the separate interest. See supra note 48 for the calculation. 
The Brandenburg formula has been explicitly adopted in several other states. ${ }^{50}$ The formula includes premarital appreciation as a separate contribution but does not include any outstanding mortgage on the dissolution date in either the numerator or denominator of the contribution fraction, because that portion of the equity has not yet been acquired. ${ }^{51}$ The formula reflects the idea that appreciation during the course of the marriage should be allocated between the two estates based on their relative contributions to the home's value. In a case like that of Harry and Sally, the prevailing thought is that, because the out-of-pocket contributions of each estate to the home's value are equal, it is proportionate and fair to allocate all of the equity, including appreciation, on an equal basis. Closer analysis reveals, however, that the allocation produced by this formula is neither proportionate nor fair due to its failure to consider the different timing of the separate and marital estates' contributions to the value of the home.

\section{The Overlooked Importance of Time}

Under the Brandenburg formula, home appreciation is allocated at only two moments in time: first upon marriage, then again on the dissolution date. This approach renders the formula unfair and in conflict with general economic principles in two important ways.

First, the formula ignores the fact that the passage of time is economically significant. Investors expect to be compensated for deferring other uses of their money ${ }^{52}$ and an earlier investment is expected to be worth more than a later one in most cases, if only because of the effect of inflation over time. ${ }^{53}$ Thus, basic economic theory reveals that a proportionate and fair return on an investment of multiple years should be greater than that on an investment of one year. The Brandenburg formula, however, ignores the critical importance of time in allocating appreciation in hybrid-property homes between the separate and marital estates.

Second, the formula fails to match the investment made by each estate to the actual returns allocable to the investment. ${ }^{54}$ Instead, the return allo-

50 Georgia, Missouri, Virginia, and West Virginia rely on Brandenburg in employing this formula in at least some cases. See Snowden v. Alexander-Snowden, 587 S.E.2d 54, 55-56 (Ga. 2003); In re Marriage of Herr, 705 S.W.2d 61 9 , 625 (Mo. Ct. App. I986); Hart v. Hart, 497 S.E.2d 496, 504-05 (Va. Ct. App. I 998); Whiting v. Whiting, 396 S.E.2d 4I3, 422 (W. Va. I 990).

5 I Turner, Equitable Distribution, supra note $34, \S 5: 25$. Turner mistakenly states that Brandenburg itself does not include premarital appreciation as a nonmarital contribution, see $i d$. $\$ 5.25 \& \mathrm{n}$.I, but the case itself makes it clear that this is included. Brandenburg v. Brandenburg, 6I 7 S.W.2d 87I, 872 (Ky. Ct. App. I98I) (explaining that "[n]onmarital contribution (nmc) is defined as the equity in the property at the time of marriage").

52 See infra note 56 and accompanying text.

53 See infra note 57 and accompanying text. While some investments decline in value, of course, no rational investor would knowingly choose an investment that is assured to do that.

54 William Reppy raised a similar concern with allocating the equity in hybrid-property 
cated to each estate is proportionate only to the dollar value of the respective investments on the dissolution date, a methodology that ignores the importance of the timing of the contributions to the home's equity and of the appreciation of the home's value over the entire course of the marriage. Indeed, the Brandenburg formula recognizes the importance of timing, but only in one way: by including premarital appreciation as a contribution by the separate estate. This treatment of premarital appreciation, without a similar consideration of time in fixing the degree of ownership of later appreciation by the separate and marital estates, places the Brandenburg formula in conflict with itself..$^{55}$

1. A long-term investment should usually produce a higher return than a shortterm investment.-Economic theory tells us that investors expect to be compensated for the use of their money: even setting aside any difference in risk, there is an expected rate of return for the inability to use funds in a different way while they are invested in an asset. ${ }^{56}$ Moreover, the simple lapse of time is significant due to inflation. ${ }^{57}$ As a rule, assets invested appreciate in value over time due to general price increases independent of growth in value. ${ }^{58}$ Thus, assets invested for a longer period of time are ex-

businesses upon divorce, noting that Brandenburg-type formulas fail to match the timing of the marital estate's investment with the business's appreciation. Reppy, supra note I 8, at 80$8 \mathrm{I}$. In that context, Reppy recommended alternating between the two competing allocation formulas for closely-held businesses on an annual basis, depending on the specific factors that most influenced the change in value of the business for the year. $I d$. at 86 . The New Mexico and California Supreme Courts have at times used a formula for dividing equity in hybrid property that takes time into account in one way: it provides the separate estate with a return between purchase and marriage equal to that expected for a well-secured, longterm investment. See Dorbin v. Dorbin, 73 I P.2d 959, 964 (N.M. Ct. App. I 986) (discussing this formula as applied to a hybrid-property home); Pereira v. Pereira, I03 P. 488 (Cal. I909) (applying the formula to a business with separate and community property components). This formula applies only to premarital appreciation allocations, not marital allocations, though; the entire appreciation during the term of the marriage is allocated to the community estate in both cases.

55 It may well be that the Brandenburg court would agree that timing is critically important and endorse the relative-interest approach set forth in this Article if it were deciding the case today. See infra Part IV.B and accompanying text (discussing technological changes in the past twenty years that make an economically sound allocation of appreciation more cost-effective and administratively feasible today).

56 See Richard A. Brealey et al., Principles of Corporate Finance i 48 (8th ed. 2006) (showing that, after adjusting for inflation, an investment in long-term U.S. Treasury bonds paid a premium of I. $2 \%$ over U.S. Treasury bills, a short-term investment, during the period I 900-2000); Jennifer L. Blouin, Pocket MBA: Finance for Lawyers Summer 20II, Practicing L. INST., June I 7, 20I I, at 426-28.

57 See Brealey et al., supra note 56, at $642-44$ (discussing inflation and the effect on nominal interest rates).

58 See Roger G. Ibbotson \& Rex A. Sinquefield, Stocks, Bonds, Bills, and Inflation (Year-end 1925-2004), Iввотson Assocs. (March 2005), http://faculty.upj.pitt.edu/gmDick/courses/Seminar/johnMaritn/Financial\%20Planning\%20 I o \% 20Syllabus\%20\&\%20PDFs/Stocks,\%20 
pected to produce a higher rate of return than those invested for a shorter period of time.

In the case of the hybrid-property home owned by Harry and Sally, the down payment and early mortgage payments were made by Harry from his separate funds, predating the marriage and the couple's joint investments. Thus, Harry's separate funds were tied up in the investment for a longer period of time and unavailable for use elsewhere; Harry could not have invested the funds in another way even if a lucrative opportunity to do so had become available. Moreover, because those funds were invested for longer than the funds contributed by the marital estate, they most likely lost value against later-invested amounts because of inflation if they are not allocated a greater share of the return from the house than the later marital investments. As a result, a fair return on the earlier separate contribution to the home should be higher than the return on the later marital contributions even after the marriage date. The Brandenburg formula, however, ignores this difference in the timing of the estates' investments altogether.

Harry's separate contribution in the example - the net equity at marriage-was made in its entirety as of the marriage date in December 1999. ${ }^{59}$ The marital contributions began shortly thereafter with the January 2000 mortgage payment but did not equal the value of Harry's separate contribution until more than six years later. ${ }^{60}$ While the Brandenburg formula produces a total return of nearly $265 \%$ for each estate ${ }^{61}$ the annual rate of return $^{62}$ is much higher for the marital estate's investment than for the separate estate's investment because the marital estate has a much shorter investment timeframe. Indeed, on an annualized basis, the separate estate's rate of return during the marriage under the Brandenburg formula is almost twenty-two percent, ${ }^{63}$ while the marital estate's annual rate of return on

Bonds,\%20Bills\%20and\%20Inflation.cfg.pdf (showing an average annual inflation rate of $3.0 \%)$.

59 While the down payment and mortgage principal payments were made earlier, the appreciation from the premarital time period is allocated to the separate estate on marriage under the Brandenburg formula. Thus, the relevant time difference in investment timing is that between the marriage date and each subsequent marital contribution.

60 Only after the lump sum $\$ 65,000$ payment in December 2005 were the marital contributions almost equal to the separate contributions, and they did not fully equal the separate contribution until after the June 2006 mortgage payment. See infra Appendix A for a monthly breakdown of the contributions to the home's value.

6I Each estate is allocated $\$ 310,000$. $\$ 85$,000 of this is a return of the estate's contribution; the remaining $\$ 225,000$ is appreciation. Thus, $\$ 225$, 000 appreciation $/ \$ 85$, 000 investment $=2.64706$, or a $264.706 \%$ rate of return.

62 The annual rate of return is calculated based on the amount of appreciation (here, $\$ 225,000)$ allocated to each estate's investment, as though it is a rate of return compounded at the end of each investment year.

63 To determine the periodic rate of return for compound interest where the future value, principal, and number of compounding periods are known, the future value is divided by the principal. This quotient is equal to the sum of I plus the interest rate, raised to the number 
its investments under the Brandenburg formula is more than four times that rate-an astounding ninety-two percent. ${ }^{64}$ The practical impact of this difference is profound. If the marital estate were afforded a twenty-two percent, rather than a ninety-two percent, annual return, considering the time and amount of each incremental investment, the appreciation allocated to it would be only $\$ 20,000$ - that is, $\$ 205,000$ less than the Brandenburg formula allocates to it. ${ }^{65}$

Put simply, in contradiction to basic economic theory the Brandenburg formula produces a far lower return on an annual basis for the earlier separate interest in a hybrid-property home than for the later-invested marital interest.

2. The investments and their returns are not properly matched under the Brandenburg formula.-In a hybrid-property home like Harry and Sally's, the separate estate's contributions to the home predate the marital estate's contributions. Thus, when the home's net equity is classified on the date of marriage, the separate interest has made $100 \%$ of the contributions up to that date. Over time, however, as mortgage principal payments continue to be made, but now from marital funds, an ever-increasing percent of the home's contributions are made by the marital estate. For Harry and Sally, the marital estate's share of the contributions rises gradually through the six-year term of the mortgage from zero percent (at marriage), to 2.5\% (after the first year's mortgage payments), to eight percent (after almost six years), to fifty percent (on the dissolution date). ${ }^{66}$

of compounding periods. Here, there are 6.5 compounding periods (the end of each year of the marriage plus the trailing six months in 2006). For the separate interest, the future value is $\$ 3 \mathrm{I} 0,000$ and the principal is a constant $\$ 85,000$, so that the annual rate of return during the marriage on this investment is $21.934 \%$.

64 See infra Appendix C for an annual calculation of the return afforded the marital contributions under Brandenburg. Once again, this assumes that all mortgage payments were made on the last day of the period. If, instead, they were made on the first day, the annual rate of return would be 7 I.2775\% to yield a final allocation of $\$ 3$ I 0 ,000. The actual annual rate of return, given that mortgage payments are generally made each month, is somewhere between the two figures. For purposes of this discussion, though, the point is the same: allocating the same total return to the separate and marital investments produces a much higher annual rate of return on the marital investment than on the separate investment.

65 More precisely, its equity allocation would be $\$ 105,044 ; \$ 85,000$ of which is a return of capital invested and $\$ 20,044$ of which is appreciation. See infra Appendix B. This calculation assumes that mortgage principal payments are made annually on the last day of the period. Even if the payments are assumed to be made in advance (on the first day of each period), a 2 I.934\% annual rate of return would yield a total equity allocation of only $\$ I_{1}{ }_{5}, 325 ; \$ 30,325$ of which is appreciation. As noted, supra note 64 , the precise percent will be somewhere between the two rates, since mortgage payments are generally made monthly.

66 See infra Appendix D for annual calculations of the shift in relative interests for the separate and marital estates. 
Despite these shifts in the estates' contribution percentages through time, the Brandenburg formula allocates the post-marriage appreciation only once: upon the dissolution date. This result is as disproportionate and unfair as if the calculation were done only on the day of marriage so as to allocate the home's entire subsequent appreciation to Harry's separate share. When allocating appreciation that has occurred over a long period of time, it simply makes no sense to choose a single date and assign to it determinative significance.

It is also important to note that the change in the value of Harry and Sally's home was not linear. As is true with most homes, in some periods it appreciated quickly (showing, for example, a $7.39 \%$ change in value during the second quarter of 2005). ${ }^{67}$ In other periods, it appreciated slowly (increasing in value by only $0.34 \%$ in the first quarter of 2006). Indeed, if the time period were shifted so that the marriage lasted through the third quarter of 2006, the home's value would have declined by $\$ 7799$ (or 1.07\%). ${ }^{68}$

Under the one-time allocation approach of the Brandenburg formula, periodic changes in the value of a hybrid-property home are simply ignored. The return on each estate's investment becomes disconnected from the risk the estate has assumed through its then-current interest in the house. Without allocating appreciation between the estates each time their relative investment interests change, a court cannot possibly divide the equity in a hybrid-property home proportionately and fairly.

\section{Other Formulas are Similarly Flawed}

While the Brandenburg formula is commonly used, some courts have developed other formulas for dividing the equity in hybrid-property homes. For example, in some states premarital appreciation is not included in calculating the separate estate's contributions. Instead, this appreciation is allocated between the estates at the same time, and in the same percentage, as appreciation that occurs during the marriage ${ }^{69}$ In other jurisdictions,

67 Other than as specified, see infra Appendix E for all quarterly rates of return calculations.

68 Change in value for third quarter 2006 based on the Federal Housing Finance Agency's ("FHFA") House Price Index Calculator for the Washington, D.C. metro area. Assuming a $\$ 730,000$ value at the end of the second quarter of 2006, the home's value would be $\$ 722,20$ I three months later, a loss of 1.07\% of its value. See HPI Calculator, Fed. Hous. Fin. Agencr, http://www.fhfa.gov/default.aspx?Page=86\&Area=MSA\&AreaID=47894\&PurchaseQtr=2006 Q2\&ValuationQtr=2006Q3\&Price=730000 (last visited Dec. 30, 20 I I ) [hereinafter HPI Calculator]. For a discussion of the allocation of equity where a home's value has declined in value, see infra Part III.C.

69 See, e.g., Thomas v. Thomas, 377 S.E.2d 666, 670 (Ga. 1989), discussed infra notes 7 I-72; Stroh v. Stroh, 383 N.W.2d 402, 405-07 (Minn. Ct. App. 1986) (relying on Schmitz v. Schmitz, 309 N.W.2d 748 (Minn. I98I), discussed infra notes 73-74 (noting that no credible evidence of change in the hybrid-property home's value between purchase and marriage was 
courts allocate all appreciation due to the mortgage balance to the marital estate, as though this unpaid debt were a marital contribution, rather than allocating it proportionately between the two estates. ${ }^{70}$

For example, in calculating the wife's separate share of a hybrid-property home's value in Thomas v. Thomas, the Georgia Supreme Court did not include premarital appreciation as a contribution. ${ }^{71}$ Instead, all appreciation was divided between the separate and marital estates based on their final relative contribution percentages, even though the premarital appreciation occurred at a time when only the separate estate had made an investment in the home. ${ }^{72}$

Using a different approach, the Minnesota Supreme Court focused on the portion of the home's equity that had been "acquired" by the time of marriage in Schmitz v. Schmitz. ${ }^{73}$ Unlike the Brandenburg approach, this formula allocates all appreciation on the mortgage balance after marriage to the marital estate instead of allocating it between the estates. Moreover, the Schmitz court multiplied the separate contribution percentage by the home's fair market value on the dissolution date, instead of reducing this value by the outstanding mortgage principal as in Brandenburg. ${ }^{74}$

Like the Minnesota Supreme Court in Schmitz, the Maryland Court of Appeals in Hoffman v. Hoffman classified all appreciation allocable to the

offered by the husband)).

70 See Schmitz, 309 N.W.2d at 749-50; Mishler v. Mishler, 367 S.E.2d 385, 388 (N.C. C.t. App. I 988); see also Hoffman v. Hoffman, 6I 4 A.2d 988, 993 (Md. Ct. Spec. App. I992) (stating appreciation on the portion of the home's value funded by a mortgage was allocated to the marital estate because the couple jointly was responsible on the mortgage). This is also the pro tanto interest approach developed by California. See In re Marriage of Moore, 6 I 8 P.2d 208, 2 Io (Cal. I980).

7I Thomas, 377 S.E.2d at 669. In Thomas, the wife purchased the home approximately eight months prior to marriage. See id. at 668. She did not offer any evidence of premarital appreciation in court. See id. The formula developed by the Thomas court can be expressed as:

$$
\frac{\text { nonmarital contributions (not incl. premarital apprec.) }}{\text { total contributions (not incl. premarital apprec.) }} \times \text { net equity at dissolution }
$$

See id. at 669 .

72 However, a later Georgia case that relied on Thomas specifically included premarital appreciation as a contribution. Snowden v. Alexander-Snowden, 587 S.E.2d 54, 55 (Ga. 2003). Thus, the omission in Thomas may be due to the facts of the case, not a more general principle.

73 Schmitz, 309 N.W.2d at 750. This formula can be expressed as:

nonmarital contributions (incl. premarital apprec.) $\times$ fair market value at dissolution fair market value at dissolution

Id. This approach was also used by the North Carolina Court of Appeals in Mishler, 367 S.E.2d at 387 .

74 Because the value of the mortgage was assigned exclusively to the marital estate, the separate interest was expressed as a proportion of the home's fair market value. For an example illustrating the logic of this approach, see Stroh, 383 N.W.2d at 406. 
mortgage as marital. ${ }^{75}$ However, the Maryland court's mechanism for this differed from the Minnesota court's approach. In Hoffman, the separate contributions were divided by the sum of the separate contributions, the marital contributions, and the unpaid mortgage balance as of the dissolution date. ${ }^{76}$ Thus, the mortgage balance was treated as a marital contribution. The court explained its approach under a legal liability theory: since the Hoffmans were jointly liable on the mortgage, any benefit from the mortgage should be allocated to them jointly and not to the separate estate.

While differing in their specifics, each of these approaches ignores the timing of the estates' investments. ${ }^{77}$ Returning to the example of Harry and Sally, the wide range of allocations under the formulas becomes clear: ${ }^{78}$

\begin{tabular}{|l|l:l|}
\hline & $\begin{array}{l}\text { Separate Property } \\
\text { Value }\end{array}$ & $\begin{array}{l}\text { Marital } \\
\text { Value }^{79}\end{array}$ \\
\hline Brandenburg formuli $^{80}$ & $\$ 310,000$ & $\$ 310,000$ \\
\hline Thomas formula & $\$ 244,000$ & $\$ 376,000$ \\
\hline Schmit: formula & $\$ 222,000$ & $\$ 398,000$ \\
\hline${\text { Hoffman } \text { formuli }^{81}}^{81}$ & $\$ 161,000$ & $\$ 459,000$ \\
\hline
\end{tabular}

The variety of outcomes provided by these four formulas-all purporting to accomplish an economically-sound allocation of equity but reaching very different allocations-signals that the law in this entire area suffers from confusion and disarray. ${ }^{82}$

\footnotetext{
75 Hoffman, 6r 4 A.2d at 993.

76 Id. This formula can be written as:

nonmarital contributions (not incl. premarital apprec.) $\quad \mathrm{x}$ fair market value at total contributions (incl. unpaid mortgage balance at dissolution) dissolution

77 Moreover, the Schmitz and Hoffman formulas allocate all benefit of the leverage from the mortgage to the marital estate.

78 All values are rounded to the nearest $\$$ Iooo.

79 In each case, the marital share is calculated as being the portion of the net equity at valuation that remains after calculation of the separate interest.
}

\section{Id.}

80 The Brandenburg formula is:

$$
\frac{\text { nonmarital contributions (incl. premarital apprec.) }}{\text { total contributions }} \times \text { net equity at dissolution }
$$

See supra notes 43-44 and accompanying text (explaining the Brandenburg formula).

8 I For purposes of this table, it is assumed that the marital estate is liable on the mortgage, as was the case in Hoffman.

82 Community property jurisdictions have at times incorporated time into their valuation of the relative interests in family-owned businesses that are hybrid property. Under the 
To be sure, all of the current formulas share one important characteristic: each is straightforward and easy to apply. Because they value the home and the contributions only on the date the home is purchased or on the marriage date, and then again at dissolution, ${ }^{83}$ they require little recordkeeping and only simple calculations. Yet if simplicity is their virtue, it is also their fatal flaw because it subverts economic reality and produces unjust results. By ignoring the relative timing of investments, each formula conceals a substantial and unacknowledged transfer of wealth from the separate to the marital estate. ${ }^{84}$

\section{Developing an Economically-Sound Approach}

State courts and legislatures generally express a preference for allocating the appreciation of hybrid-property homes "proportionately" between the separate and marital estates. ${ }^{85}$ However, the equity in homes is generally acquired over time, with each mortgage payment or other contribution. To be truly proportionate, appreciation in these cases must be allocated each time the estates' relative interests in the property change, in proportion to each estate's then-existing investment, including prior allocations of appreciation. In other words, proportionate allocation requires an on-going stream of allocations that takes account of the multiple contributions that have been made over time. The law, in fact, already recognizes this key point. Indeed, courts divide the value of defined-contribution retirement plan accounts that are hybrid-property between the separate and marital estates upon divorce using this methodology.

Pereira approach, see supra note 54, a fair annual return based on prevailing interest rates is calculated. Pereira v. Pereira, I03 P. 488, 493 (Ca. I909). Any appreciation above this amount is allocated to the marital share. Id. Contrarily, under the Van Camp line of cases, a reasonable salary is imputed to a spouse working in a separate-property business. Van Camp v. Van Camp, I 99 P. 885, 888 (Ca. I92 I ). This amount is allocated to the marital estate, with any excess appreciation classified as separate property. $I d$. However, these approaches are applied so as to consistently maximize the marital share, but are disconnected from the actual appreciation of the businesses. See Reppy, supra note i 8, at 65, 92.

83 This valuation is generally either the net sales price, if the home is sold on or before the dissolution date, or the appraised value.

84 See supra notes 26-3 I and accompanying text for a discussion of when separate property is transparently and intentionally transmuted into marital property. This Article does not argue against such an approach. Instead, it is the hidden-and perhaps unintended-nature of the transfer with respect to the equity in hybrid-property homes that is questioned.

85 See supra note 16 for courts that express that allocations of appreciation should be proportionate to the estates' investments in a home. 


\section{A. Dividing the Value of Defined-Contribution Retirement Plan Accounts}

Like homes, retirement plan accounts represent a significant portion of wealth for many Americans. ${ }^{86}$ Also, as with homes, value in these accounts is acquired over time, as periodic contributions are made by an employee (and sometimes the employer). ${ }^{87}$ In many instances, contributions are made initially by an unmarried employee and continued after the marriage. Therefore, upon divorce, the retirement account is hybrid property and its value must be divided between the separate and marital estates. ${ }^{88}$

The preferred method for dividing the value of a hybrid-property retirement account between the separate and marital estates is the "relative-value" approach. ${ }^{89}$ This approach allocates gain as it accrues between the separate and marital estates based on their then-respective investment percentages, as adjusted for prior gain allocations. ${ }^{90}$ Each increment of appreciation so allocated, then, increases the estate's relative base for calculating its share of the next unit of appreciation. Put another way, actual returns on each estate's contributions are matched to the relative interests of each estate as of each contribution date, and the returns are compounded. ${ }^{91}$ This approach takes close account of the timing of the contributions and their associated returns.

86 See Bucks et al., supra note 3, at Ar 5, A20 (finding that $57.7 \%$ of American families owned retirement plan assets, which comprised $34.6 \%$ of their total financial holdings in 2007); Eric L. Olsen, How Should the Community Interest in Pension Benefits be Determined Upon Dissolution of the Marital Community?, 28 IDaho L. Rev. I07 I, I07 I (1992) ("Pensions usually comprise the most significant community asset.").

87 This is true for "defined-contribution" accounts, like $40 \mathrm{I}(\mathrm{k})$ accounts. By contrast, the value of an employee's "defined-benefit" retirement plan benefits is independent of financial contributions made by the employee. Instead, these plans provide a stated level of benefits to the employee, generally based on a percentage of the employee's salary and the number of years of service. See Law of Family Dissolution, supra note 20, $\$ 4.08$. While the benefits of defined-benefits plans can also be hybrid property, different considerations are involved in valuing the interests in them than with hybrid-property homes. Because the equity in a defined-contribution account is acquired analogously to equity in a home financed by a mortgage, defined-contribution accounts are the focus of this section.

88 While the financial patterns of investing in homes and in retirement accounts are different-for example, in homes, the down payment is often the single most substantial contribution to the home's value, whereas contributions to retirement accounts are generally lower in the early years of employment-the allocation problems presented by the progressive investments over time are similar between these two types of assets.

89 See, e.g., Law of Family Dissolution, supra note 20, $\$ 4.08 \mathrm{cmt}$. f. Where the information needed for the effective application of the relative-value rule is not available, a "relativetime" rule is used to allocate value in a defined-contribution account between the estates. Id.

90 See 3 Matthew Bender, Valuation and Distribution of Marital Prop. ch. 45 $\S 45.09(5)$ (b) (20 I I) (describing the mechanics of the relative-value approach).

9I This compounding of the return is the same as with other financial investments where the return is not withdrawn when earned, like savings accounts. 
The relative-value approach to dividing the value of hybrid-property defined-contribution accounts stands in stark contrast to the Brandenburg formula. It reflects the reality that any fair judicial allocation of appreciation must account for the different timing of the underlying contributions and returns instead of crudely and artificially fixing the relative contributions of the separate and the marital estates at a single moment in time. ${ }^{92}$ In particular, the core principle of the relative-value approach is exactly the principle that the Brandenburg formula rejects-namely, that there should be a proportionately greater return accorded to the early separate contributions than to the later marital ones because of the compounding of investment returns through time. ${ }^{93}$

This relative-value approach has never been used in allocating the equity in hybrid-property homes upon divorce. Close examination, however, shows that there is no good reason for the highly contradictory treatment of these two closely analogous situations. ${ }^{94}$ In the pages that follow, this Article develops a "relative-interest" approach for dividing the equity in a hybrid-property home between the separate and marital estates. This approach is modeled on the relative-value approach used in the retirement account context, but also accounts for the distinct issues involved with the valuation and financial division of hybrid-property homes.

\section{B. The Relative-Interest Approach: Methodology}

The home's net equity on the date of marriage serves as the starting point for a relative-interest approach to classifying the equity in a hybridproperty home. This equity, which includes the down payment, premarital mortgage principal payments, the value of any premarital improvements to the home, and premarital appreciation in the home's value, is properly classified as the separate estate's interest in the home as of the time of marriage because it represents the separate estate's premarital investment and

\footnotetext{
92 See Law of Family Dissolution, supra note $20, \S 4.08 \mathrm{cmt}$. f.

93 See id. \$ 4.08 reporter's notes on cmt. f.

94 While the value of a defined-contribution account is almost always easier to determine than the value of a home because the underlying securities are usually fungible and publicly-traded, other complexities exist. For example, in many cases the employer-match portion of contributions only vests over time, or tax and other prohibitions on transfer mean that nonmarital contributions begin to be made again to the same account after marital dissolution, without prior segregation of the assets allocated to the non-employee-spouse. See generally id. $\$ 4.08$ reporter's notes on cmt. e (discussing various caselaw on post-divorce costof-living increases in defined-contribution plans); Susan J. Prather, Characterisation, Valuation, and Distribution of Pensions at Divorce, i 5 J. Am. Acad. Matrimonial Law. 443, 455-63 ( i998) (describing the various ways courts may calculate a non-employee spouse's entitlement to an employee-spouse's benefits). Thus, while there are complexities associated with the use of the relative-interest approach, there is no reason they cannot be overcome in the home context just as they have in the retirement account context.
} 
the return on that investment. Because the entire net equity is allocated to the separate estate, the dates and amounts of the premarital contributions do not need to be recorded. Instead, an appraisal as of the date of marriage can be obtained, or, if no improvements were made to the home, an index-that is, a specialized real estate database that calculates the change in value of the typical home in a given geographic area over a defined time period-can be used to measure the value of the home, including premarital appreciation. ${ }^{95}$ This value, reduced by the outstanding mortgage principal (and any other secured debt on the home) ${ }^{96}$ constitutes the full separate interest in the home on the marriage date.

After the separate interest at the time of marriage is calculated, any change in the home's net equity between the marriage and the first marital contribution ${ }^{97}$ must be allocated to the separate estate. After all, because no marital contribution has yet been made to the home's equity, there can be no appreciation attributable to the marital estate during this timeframe. Once the initial marital contribution is made, however, things change. From this point forward, any appreciation that occurs must be allocated between the separate and marital estates based on their relative interests in the home.

95 For purposes of this Article, all changes in value are from the online House Price Index Calculator provided by the FHFA, discussed supra note 68 . This calculator uses the data in the FHFA Purchase-Only House Price Index to calculate the change in value in homes for 384 geographic areas in the U.S. and on a national basis, based on repeat sales of single-family homes. It contains data from more than 42 million transactions. Press Release, Fed. Hous. Fin. Agency, House Price Index Falls o.8 Percent in Fourth Quarter 20 I0; House Prices Decline in Most States, 2, 23 (Feb. 24, $20 \mathrm{I}$ I ), available at http://www.fhfa.gov/webfiles/I 98 I o/4q20 IoHPI. pdf [hereinafter FHFA 20 Io Press Release]. The data are available on a monthly basis since 2008 and quarterly since 1975. See Monthly HPI, Fed. Hous. Fin. Agency, http://www.fhfa.gov/ Default.aspx?Page $=85$ (last visited Nov. I I, 20I I). Data including home refinancings, often considered less reliable than purchase-only data, are available for download from the FHFA from 1975 through the present. E-mail from Help Desk, Fed. Hous. Fin. Agency, to author (Aug. 8, 20I I, I0:48 EST) (on file with author) [hereinafter FHFA Help Desk E-mail].

The indexes available from S\&P/Case-Shiller are an alternative source for home price change data. These indexes provide monthly data for homes nationally and on a per-zip code basis for twenty metropolitan regions. S\&P/Case-Shiller Home Price Indices, STANDARD \& PooR's http://www.standardandpoors.com/indices/sp-case-shiller-home-price-indices/en/ us/?indexId=spusa-cashpidff--p-us---- (last visited Nov. I I, 20I I) [hereinafter S\&P/CaseShiller Home Price Indices]. Within those twenty regions, the available indexes are more finelytailored than the FHFA's index, but S\&P/Case-Shiller charges a fee for access to the data.

For an in-depth analysis of the difference between the FHFA and S\&P/Case-Shiller indexes, see Andrew Leventis, Revisiting the Differences Between the OFHEO and S\&8P/Case-Shiller House Price Indexes: New Explanations, Off. Fed. Hous. Enter. Oversight (2008), http://www. fhfa.gov/webfiles/ I i63/OFHEOSPCS I 2008.pdf.

96 Examples of other secured debt would be a home equity loan or home equity line of credit ("HELOC").

97 This contribution will usually be the first mortgage principal payment made from income earned during the marriage. 
At this point, the marital estate's interest is equal to its initial contribution, because that is the only contribution of any kind the marital estate has made to the home's equity. The balance of the home's equity is the separate estate's interest. ${ }^{98}$ Each of these interests must be divided by the sum of the total interests in the property-the separate interest plus the marital interest-to determine each estate's initial allocation percentage. At the time of the next marital contribution, any appreciation that has accrued since its initial contribution is allocated between the estates based on their allocation percentages, increasing their respective interests, and the marital estate is then also credited with its second contribution. Each estate's interest is updated and its allocation percentage is recalculated in a similar fashion each time there is another contribution. With a typical mortgage, these calculations and allocations need to be performed on a monthly basis. Through this process, the timing-both of the contributions and of the appreciation-is taken into account. ${ }^{99}$

As the preceding discussion suggests, contributions after marriage will usually be marital contributions. In such a case, use of the relative-interest approach gradually increases the marital estate's share of the home's value during the course of the marriage, reflecting that estate's ever-increasing investment in the home over time. Sometimes, however, funds will come from one spouse's separate property. This could happen, for example, if an improvement or mortgage principal payment was financed by a bequest from a grandparent to a particular spouse or from that spouse's segregated premarital bank account. When funds do come from a separate source, the contribution is credited to that spouse's separate interest. ${ }^{100}$

If the couple sells the home prior to divorce, the net sales proceeds should be used as its final value. If not, the home should be appraised as of the dissolution date. Any difference between the sales proceeds or ap-

98 Alternatively, this can be calculated by adding the separate interest at the time of marriage (the home's net equity) to the appreciation that occurred during the marriage but prior to the first marital contribution.

99 Technically, this is only required each time a disproportionate contribution is made; if all contributions are proportionate to the then-current interests, no allocation of appreciation is needed until a contribution that changes the relative interests in the home is made. However, such matching should only occur if a couple is intentionally blending separate and marital contributions to maintain the existing interest ratios. Any withdrawal of equity-for example, a drawdown of a HELOC—-should similarly be allocated as a negative contribution to the appropriate estate with such estate's interest for future periods' appreciation reduced accordingly.

Ioo Thus, there could be three interests in a hybrid-property home, if the spouse who did not originally purchase the home later made separate property contributions to its value. However, this would not change the required analysis. Instead, the respective value of all three estates' interests-the first spouse's separate estate, the second spouse's separate estate, and the marital estate-would need to be calculated each time there was a further contribution to the home's value and again upon the dissolution date. The relative-interest allocation process would remain the same despite the investment by a third estate. 
praised value and the previous indexed valuation will constitute the home's final increment of appreciation and should be allocated between the separate and marital estates based on their final allocation percentages. ${ }^{101}$

By allocating appreciation between the separate and marital estates each time their respective investments change, the relative-interest approach takes into consideration the timing of each investment made in the property and its associated returns. Thus, each estate receives the benefit - and bears the risks - of the actual investments it has made.

\section{The Relative-Interest Approach: An Example}

To illustrate the operation of the relative-interest approach, this section returns to the example of Harry and Sally. ${ }^{102}$ Under the relative-interest approach, Harry's separate interest initially equaled the home's net equity $(\$ 85,000)^{103}$ on the date of marriage. The home appreciated further

I I Similarly, if the home is sold by the dissolution date, its net equity at the time of the sale should be used as the final value for allocation purposes.

I02 Recall that Harry purchased the home in December I 997 for $\$ 250,000$. He financed it with a $\$ 50,000$ down payment and a $\$ 200,000$ mortgage. Assume that the mortgage was a fully-amortized thirty-year mortgage at $6.5 \%$. When Harry and Sally married in early January I 999, the home was valued at $\$ 280,000$ and its net equity was $\$ 85,000$ due to the down payment $(\$ 50,000)$, premarital mortgage principal payments $(\$ 5000)$, and premarital appreciation $(\$ 30,000)$. After their marriage, Harry and Sally made the required monthly mortgage payments and, in December 2005 , they made an additional payment of $\$ 65,000$ from their yearend bonuses. Dissolution of the marriage came at the end of June 2006. The home's appraised value at that time was $\$ 730,000$ and there was an outstanding mortgage balance of $\$$ I I0,000, so that they had $\$ 620$, 000 in net equity to divide.

I03 The home's value, outstanding mortgage principal balance and net equity at the end of each year and on the dissolution date are:

\begin{tabular}{|l|l|l|l|l|l|}
\hline Year & $\begin{array}{l}\text { End of Year } \\
\text { House Value }\end{array}$ & $\begin{array}{l}\text { Total Monthly } \\
\text { Principal Payments }\end{array}$ & $\begin{array}{l}\text { Additional } \\
\text { Contributions }\end{array}$ & $\begin{array}{l}\text { Mortgage Principal } \\
\text { Balance }\end{array}$ & Net Equity \\
\hline 1997 & $\$ 250,000$ & $\$ 0$ & $\$ 50,0000$ & $\$ 200,000$ & $\$ 50,000$ \\
1998 & $\$ 262,069$ & $\$ 2500$ & $\$ 0$ & $\$ 197,500$ & $\$ 64,569$ \\
1999 & $\$ 280,000$ & $\$ 2500$ & $\$ 0$ & $\$ 195,000$ & $\$ 85,000$ \\
2000 & $\$ 311,905$ & $\$ 2600$ & $\$ 0$ & $\$ 192,400$ & $\$ 119,505$ \\
2001 & $\$ 358,501$ & $\$ 2700$ & $\$ 0$ & $\$ 189,700$ & $\$ 168,801$ \\
2002 & $\$ 412,218$ & $\$ 2900$ & $\$ 0$ & $\$ 186,800$ & $\$ 225,418$ \\
2003 & $\$ 473,104$ & $\$ 3100$ & $\$ 0$ & $\$ 183,700$ & $\$ 289,404$ \\
2004 & $\$ 588,257$ & $\$ 3300$ & $\$ 0$ & $\$ 180,400$ & $\$ 407,857$ \\
2005 & $\$ 702,460$ & $\$ 3500$ & $\$ 65,000$ & $\$ 111,900$ & $\$ 590,560$ \\
2006 & $\$ 730,000$ & $\$ 1900$ & $\$ 0$ & $\$ 110,000$ & $\$ 620,000$ \\
\hline
\end{tabular}

See infra Appendix A, for a detailed schedule showing the quarterly valuation and contribution schedule. All valuation data is from the FHFA House Price Calculator for the Washington, DC-Arlington-Alexandria metro area. See supra note 68. The fourth quarter I 999 and second quarter 2006 are treated as appraisals in this analysis and represent rounded valuations, not the exact values from the index. All principal payment data is from the mortgage calcu- 
in January 2000 (\$1765), ${ }^{104}$ and this appreciation increased Harry's separate interest because it predated the first marital contribution. After the first marital contribution-the $\$ 206$ mortgage principal payment at the end of January - the allocation percentages would be calculated for the first time, and February's appreciation allocated between the estates based on their relative interests in the home.

Harry's separate allocation percentage for February would be equal to his cumulative interest at the start of the month divided by the home's net equity at that time. ${ }^{105}$ Similarly, the marital estate's allocation percentage would be calculated by dividing its cumulative interest at that time by the home's net equity. ${ }^{106}$ February's appreciation of $\$ 1765$ would then be allocated between the estates based on these percentages- $99.76 \%$ to the separate estate and $0.24 \%$ to the marital estate-before February's mortgage payment is credited to the marital estate. In the end, the separate estate would be increased by $\$ 1760$ and the marital estate by $\$ 5^{107}$ due to the appreciation in February.

After February's appreciation has been allocated, the marital estate would be credited with the principal portion of the February mortgage payment (\$207), and the allocation percentages would again be recalculated using the cumulative interests and net equity as of the start of March. Once again, the separate estate's allocation percentage would be equal to its cumulative interest immediately after the prior month's mortgage payment divided by the home's net equity at that time, or $99.53 \%$. ${ }^{108}$ The marital estate's allocation percentage would be its cumulative interest at that time divided by the net equity, or $0.47 \%{ }^{109}$ March's appreciation of $\$ 1765$ would be allocated between the estates accordingly, so that the separate estate receives $\$ 1755$ and the marital estate receives $\$ 10$-twice as much as it was allocated in February, since it doubled its contribution to the home's

lator on Mortgage Calculator, BANKRATE.COM, http://www.bankrate.com/calculators/mortgages/ mortgage-calculator.aspx (last visited Nov. I I, 20 I I) (providing a free user-friendly mortgage payment calculator). Each period's scheduled payments have been adjusted to conform to the rounded figures used in the text of the Article.

I04 Because the FHFA's House Price Index is only calculated on a quarterly basis prior to 2008, see supra note 95, the monthly values in Appendix A assume one-third of each quarter's appreciation occurred during each month of the quarter. Through time, this type of approximation will cease to be necessary, as monthly appreciation information becomes readily available. See infra Appendix A for a detailed schedule of contributions, gain, cumulative interests, and allocation percentages. Values in the text are rounded for convenience; percentages are rounded to the nearest two decimal places based on the values in Appendix A.

I05 Using the exact appreciation value of $\$ \mathrm{I} 766$ yields: $\$ 86,766 / \$ 86,97 \mathrm{I}=99.76 \%$. The following footnotes use exact figures based on Appendix A. See infra Appendix A.

I $06 \$ 206 / \$ 86,97 \mathrm{I}=0.24 \%$. See id.

I 07 I $765.67 \times 0.9976=\$$ I 76 I $.43 ;$ I $765.67 \times 0.0024=\$ 4.24$. See id .

I $08 \$ 88,527 / \$ 88,944=99 \cdot 53 \%$. See id.

I09 $\$ 417 / \$ 88,944=0.47 \%$. See id. 
equity by making a second mortgage payment. These cumulative interest and allocation percentage calculations would then be repeated each month to reflect the monthly mortgage payments and allocate the associated appreciation, until the marriage's dissolution immediately after the June 2006 mortgage payment.

On the dissolution date, the net equity in Harry and Sally's home is $\$ 620,000$. This amount is found by subtracting the then-outstanding mortgage balance $(\$ 110,000)$ from the appraised value of the home on the dissolution date $(\$ 730,000)$. This equity should be divided between the estates based on their final allocation percentages. Harry's separate allocation percentage on the dissolution date, after the final marital mortgage payment, would be $81.38 \%{ }^{110}$ Thus, $\$ 504,525^{111}$ of the home's final net equity is classified as Harry's separate property. The marital estate's allocation percentage is $18.62 \%,{ }^{112}$ and $\$ 115,475$ is classified as marital equity ${ }^{113}$

In all, Harry contributed $\$ 55,000$ in premarital assets to the home's net equity. In addition, the relative-interest approach allocates all of the premarital appreciation $(\$ 30,000)$ and the appreciation that accrued between the time of marriage and the first marital contribution (\$1765) to him. Of the appreciation that accrued after the home became hybrid property, he is allocated $\$ 418,000 .{ }^{114}$ The marital estate contributed $\$ 85,000$ to the home's value and was allocated $\$ 30,000^{115}$ in appreciation. Is this allocation proportionate and fair?

\section{Comparing The Allocations}

The relative-interest approach to dividing the equity in a hybrid-property home classifies substantially more of the home's value as separate property than does the Brandenburg formula. Ultimately the relative-interest approach allocates $\$ 505,000$ to the separate estate while on identi-

I Io This represents the sum of the separate interest at the end of May $(\$ 497,694)$ and the separate estate's allocation of June's appreciation (\$683I), divided by the home's net equity value at the end of June $(\$ 620,000)$. See id.

I I $\$ 620,000 \times 0.81375=\$ 504,525$. See id .

I 2 This allocation percentage is calculated by adding the marital estate's interest at the end of May $(\$ 113,552)$ to its June allocation of appreciation $(\$ 1558)$ and its June mortgage principal payment $(\$ 365)$, then dividing this sum by the home's net equity on the dissolution date $(\$ 620,000)$. See id.

I $33620,000 \times 0.18625=\$$ I I 5,475 . See id.

I I 4 This represents the total separate allocation $(\$ 504,525)$ less the separate estate's down payment $(\$ 50,000)$, premarital mortgage principal payments $(\$ 5000)$, premarital appreciation $(\$ 30,000)$, and appreciation after marriage but before a marital contribution (\$1 766 ), or $\$ 504,525-\$ 50,000-\$ 5000-\$ 30,000-\$ 1766=\$ 417,759$. See id.

I 15 This represents the marital estate's allocation $\left(\$\right.$ I I $\left._{5}, 475\right)$ less its contributions $(\$ 85,000)$, or $\$$ I I $5,475-\$ 85,000=\$ 30,475$. See id . 
cal facts the Brandenburg formula would allocate $\$ 310,000$ to the separate estate. ${ }^{116}$

As a starting point, both approaches allocate the $\$ 55,000$ in premarital payments ${ }^{117}$ and $\$ 30,000$ in premarital appreciation ${ }^{118}$ solely to the separate estate. From an economic perspective, this makes sense: the separate estate is the only investor prior to marriage, and so it should receive the full the benefit of any appreciation during this time. If the home value instead declined prior to marriage, the separate estate should also bear the entirety of this loss. ${ }^{119}$

For the same reason, the relative-interest approach allocates the initial $\$ 1765$ in appreciation to the separate estate: it is the first marital contribution, not the marriage itself, that converts the home from separate to hybrid property. Thus, any appreciation prior to that first marital contribution is properly classified as separate. In mechanistic fashion, though, the Brandenburg formula splits this appreciation equally between the estates.

Under the relative-interest approach, the remaining $\$ 445,000$ in appreciation during the marriage is allocated between the estates upon each contribution of funds to the home based on their then-existing relative interests in the home at the time the appreciation occurs. The separate estate's allocation percentage was $99.76 \%$ for February 2000, just after the home became hybrid property. This allocation percentage was reduced to $81.38 \%$ at the time of dissolution. ${ }^{120}$ The marital estate's allocation percentage increases complementarily: while it was only $0.24 \%$ after its initial mortgage principal payment, by the time the marriage dissolves it increases to $18.63 \%$. Thus, ultimately $\$ 415,000$ of the appreciation while the home was hybrid property is allocable to the separate estate and $\$ 30,000$ is al-

I 6 The other formulas currently in use allocate even less to the separate estate, with Hoffman allocating only \$I6I, ooo to it, of which \$I06,000 is appreciation. See supra Part I.D.

I I 7 This includes the $\$ 50,000$ down payment and $\$ 5000$ in premarital mortgage principal payments.

I I 8 Recall that the Brandenburg formula's equity allocation is fifty percent to each of the separate and marital estates at all times after the date of marriage, since their contribution percentages at the dissolution date are each fifty percent. See supra notes 47-49 and accompanying text.

I 9 See infra Part III.C (discussing the allocation of losses under the relative-interest approach).

I 20 While the separate estate's June 2006 allocation percentage is $8 \mathrm{I} .42 \%$, this is further reduced just prior to the dissolution date due to the marital estate's $\$ 365$ mortgage principal payment that month. Thus, its allocation percentage is equal to its equity allocation at the beginning of June $(\$ 497,694)$, increased by 8 I .42\% of June's $\$ 8389$ appreciation ( $\$ 683 \mathrm{I})$, divided by the net equity at dissolution $(\$ 620,000)$ :

$\$ 497,694+\$ 6831=\$ 504,525$

$\$ 504,525 / \$ 620,000=8 \mathrm{I} \cdot 375 \%$

See infra Appendix A. 
locable to the marital estate under the relative-interest approach. Again, in keeping with its preference for simplicity, the Brandenburg formula would allocate exactly one-half of the appreciation during the marriage to each estate on the theory that each contributed an equal absolute amount to the aggregate acquisition of the home.

While the total return allocated to the separate estate under the relative-interest approach is substantially greater than that allocated to the marital estate, ${ }^{121}$ when the estates' rates of return ${ }^{122}$ are compared the result proves economically sound. The separate estate began its investment in December 1997; between that time and the first marital investment, the home appreciated $\$ 31,765 .{ }^{123}$ Because the separate estate was the only investor in the home during this time period, this entire amount was a return on the separate estate's investment. After that date, the monthly return on the separate estate's investment under the relative-interest approach was $2.32 \%$, for an annual percentage rate of $31.61 \% .{ }^{124}$ By comparison, the marital estate's monthly return on its investment was $1.89 \%$, or $25.22 \%$ annually.

The difference in the estates' rates of return is explained by the different timing of the estates' investments in the property. The bulk of the home's appreciation occurred while the separate estate was fully invested but the marital estate was just beginning to invest its funds in the home. The separate estate's most substantial contribution-the down paymentwas made in December 1997 while the marital estate's primary contribu-

I 2 I The return on the separate estate's investment is the sum of its premarital appreciation $(\$ 30,000)$, the appreciation during January 2000 ( $\$ \mathrm{I} 766)$, and the portion of the home's appreciation allocated to the separate estate while the home is hybrid property $(\$ 4$ I 7,759$)$ :

$$
\$ 30,000+\$ 1766+\$ 417,759=\$ 449,525
$$

The marital estate's return is the appreciation allocated to it periodically after its first contribution, or $\$ 30,475$.

i22 See Robert D. Feder, Valuation Strategies in Divorce $§$ i.24 (3d ed. i993) (defining "rate of return" as "[t]he amount of income realized or expected on an investment, expressed as a percentage of that investment").

I23 This is comprised of the premarital appreciation and the appreciation from January 2000.

I24 Of course, the actual appreciation was not so smooth. The annual rate that would allocate the same amount of equity to the separate estate as under the relative-interest approach is calculated here so that it can be compared to the marital estate's rate of return, despite the different investment timing and patterns. See infra Appendix E for detail of the annual returns afforded each the separate and marital estates and the annual rate of appreciation in the home's value. While the rate of return for both estates is quite high, these returns make sense since the principal producing them is, in each case, not only the estate's investment but its proportionate share of the unpaid portion of the mortgage because of the impact of leverage. For an explanation of leverage and mortgages, see Atif R. Mian \& Amir Sufi, House Prices, Home Equity-Based Borrowing, and the U.S. Household Leverage Crisis I0-24 (Nat'l Bureau of Econ. Research, Working Paper No. I5283, 2009). 
tion-the $\$ 65,000$ lump sum payment-was not made until December 2005. Between the first quarter of 2000 (when the marital estate made its first contribution to the home) and December 2005, the home's annual appreciation ranged from a low of $11.40 \%$ (in 2000) to a high of $24.34 \%$ (in 2004). The home's appreciation after full investment by the separate estate proved to be more modest than in previous years: its annualized rate of appreciation for the first half of 2006 was only $7.99 \% .{ }^{125}$ Put simply, the marital estate's rate of return on its investment was lower than the separate estate's return on its investment because the home's appreciation occurred predominantly while the separate estate was the exclusive or primary investor in the property. If the early years had been less favorable-if there had been a loss instead of a steady gain in the home's value-the separate estate would similarly have borne a high proportion of that loss under the relative-interest approach.

Of particular importance, because the relative-interest approach allocates appreciation as it occurs, each estate's investment is compounded through time. Thus, increments of appreciation from prior periods are added to contributions for purposes of calculating the subsequent period's allocation percentage. This method of dealing with prior appreciation is consistent both with typical investor expectations ${ }^{126}$ and with the Brandenburg formula's own classification of premarital appreciation. ${ }^{127}$ Given this aspect of the Brandenburg formula, later returns for Harry and Sally under Brandenburg are calculated on a base of $\$ 85,000$ because the premarital appreciation of $\$ 30,000$ is treated as part of Harry's separate contribution. Put another way, the numerator for calculating Harry's separate allocation percentage in the Brandenburg formula ${ }^{128}$ includes within it this significant portion of appreciation, increasing the share of subsequent appreciation that is allocated to the separate estate. The relative-interest approach simply picks up where Brandenburg leaves off. It treats appreciation in a consistent manner throughout the period of homeownership, rather than arbitrarily taking appreciation into account only to the extent it occurs prior to the marriage date.

The bottom line is not hard to see. The relative-interest approach to dividing the equity in hybrid-property homes is more economically sound and more just than the current formulas used in making this division.

\footnotetext{
I 25 This is the rate of return for the first half of $2006(3.92 \%)$, compounded once to produce an annual rate of return of $7.99 \%$. This is not equal to the actual return for 2006 , but is simply for comparison with earlier years.

I 26 See, e.g., Peter C. Canellos \& Edward D. Kleinbard, The Miracle of Compound Interest: Interest Deferral and Discount After 1982, 38 TAx L. Rev. 565, 565 (1983) (explaining that the value of money over time includes the value that could have been earned had it been invested, an amount that can be particularly significant due to the compounding nature of interest).

I 27 See supra note 43 and accompanying text.

I 28 This is also true under the Schmit: formula, discussed supra notes $73-74$ and accompanying text.
} 
Courts simply cannot meet the goals of honoring economic reality and basic fairness if they ignore considerations of timing that both experts and ordinary home purchasers recognize as central to investment and valuation decisions.

\section{Potential Objections to the Relative-Interest Approach}

Why might courts choose not to embrace the relative-interest approach? First, they might object to the administrative difficulties presented by the valuation of hybrid-property homes on a periodic basis over a long stretch of time. Second, they might balk at the additional record-keeping required by the approach as well as its computational complexity. Third, they might believe the approach fails to address situations in which the value of a home declines, rather than appreciates, over time. Each of these potential objections is considered below. In the end, none of them overrides the benefits provided by the relative-interest approach.

\section{A. Addressing Home Valuation Concerns}

To use the relative-interest approach, a court must be able to determine the change in a home's value between each contribution. While historically this information was difficult and costly to obtain, ${ }^{129}$ now easily available, geographically specific indexes provide extensive monthly or quarterly data on housing price changes. For example, the Federal Housing Finance Agency ("FHFA") provides a free, online "House Price Calculator," which provides information on the changes in house values in 384 metropolitan regions as well as nationally, based on the "House Price Index" maintained by the FHFA. ${ }^{130}$ Current data is available on a monthly basis. ${ }^{131}$ Alternatively, S\&P/Case-Shiller provides a monthly home price index for zip codes in twenty urban regions for a fee. ${ }^{132}$ In addition, the Census Bureau maintains the free Constant Quality House Price Index, which incorporates data from approximately 14,000 home sales each year based on monthly surveys. ${ }^{133}$ While no index will provide accurate valuation data for any specific house, each of these indexes can provide a reliable estimate of the typical change in the value of homes in the covered regions on a periodic basis. ${ }^{134}$

I29 See infra note 157 (discussing availability of FHFA data prior to I975).

I30 See FHFA 20 io Press Release, supra note 95, at 22. The FHFA's House Price Calculator and House Price Index are discussed in more detail in Part II of this Article. See supra notes 95 \& 104 and accompanying text.

I3 I For periods prior to 2008, the data are available on a quarterly basis. Data from before I 975 are available only on an as-requested basis. See FHFA Help Desk E-mail, supra note 95.

I32 S\&P/Case-Shiller Home Price Indices, supra note 95.

I33 FHFA 2010 Press Release, supra note 95, at 23.

I34 Realtors also informally track price changes in sales prices in their areas; while com- 
The changes in the value of a home can be reasonably and affordably tracked through the use of such databases, and, thus, the gain can be allocated each time the relative investments in the home change. To the extent a particular home appreciates more or less than the "typical" home in the index used, the net equity is ultimately allocated based on the house's sale proceeds or appraised value as of the dissolution date, tying the division of equity to the particular home's value. While the relative-interest approach determines how the available equity is allocated between the estates using the data available in the indexes, an appraisal or sale is needed to determine how much equity there is to be divided.

Although the available home price-change data is, ultimately, an approximation of the typical home's change in value in the relevant geographic market during the selected time period, it far more accurately reflects economic reality than do the current formulas. ${ }^{135}$ Indeed, from an economic perspective, the Brandenburg formula assumes in effect that all appreciation in the home occurs in the time period between the last predivorce contribution and the dissolution date regardless of the length of the marriage or the actual pattern of appreciation. To say that such an approach should be retained because periodic valuation tools are imperfect is to allow a very small tail to wag a very large dog.

\section{B. Managing the Increased Complexity of the Approach}

The records and calculations needed to apportion a hybrid-property home's change in value with each contribution are more complex than those required under current formulas. Indeed, the current approaches require nothing more than tracking the contribution amounts and calculating the allocation percentages as of a single date. The relative-interest approach requires something more-namely, that the dates of the contribu-

prised of a smaller data set and more likely to contain data about discrete sales than repeat sales of the same home, this is yet another source of periodic revaluation data for homes Moreover, Zillow provides "Zestimates," which are estimates of home value calculated using market data. See Zillow, www.zillow.com (last visited Aug. 23, 20 I I). By Zillow's own admission, Zestimate accuracy varies by metropolitan area, with far greater accuracy in Los Angeles than San Antonio, for example. Data Coverage and Zestimate Accuracy, Zillow, http:// www.zillow.com/howto/DataCoverageZestimateAccuracy.htm (last updated June I5, 20II) Zestimates are available for 97.3 million American homes, but the figures are based on public records, which may contain inaccurate information. Robbie Whelan, Zillow 'Zestimate' Shifts, Prompting Howls, Wall St. J. Devs. Blog (July 6, 201 I , 4:57 PM), http://blogs.wsj.com/developments/20 I I/07/06/zillow-zestimate-shifts-prompting-howls. Both Zillow and its critics assert that a Zestimate is not a substitute for an appraisal, but it remains a useful tool for tracking home values over time. Id.

I35 Moreover, to the extent the relative-interest approach is adopted, through time it is likely that the available data will improve, both because it is already improving and because, through the added demand, the services collecting relevant data should have added incentive to provide it in ways that will facilitate use of the approach. 
tions be recorded. Put another way, it is not enough to know only what was contributed, but it is also necessary to know when the contributions were made. Moreover, each estate's interest and resulting allocation percentages must be recalculated in light of each additional contribution on a continuing basis, perhaps over a long period of time. ${ }^{136}$

On close analysis, however, these added requirements only marginally increase the administrative burden of the relative-interest approach. Dates for unusual payments can normally be obtained based on credit card receipts, cash withdrawal dates, or checking account statements. Online amortization calculators provide a monthly breakdown of scheduled principal payments, ${ }^{137}$ and homeowners can request schedules specific to their loans from the lender. Moreover, once a template is developed and data entered, the calculations themselves are entirely mechanical. Indeed, the calculations involve exactly the same arithmetic as other current formulas. The only difference is that the calculations for the relative-interest approach must be repeated with each contribution-a simple matter given existing computer technology. ${ }^{138}$

In any event, while simplicity is a worthwhile goal, it alone is inadequate to justify vast transfers of wealth. Individuals surely prioritize accuracy over mathematical ease in the allocation of their wealth, particularly when tens or hundreds of thousands of dollars are at stake. ${ }^{139}$ When investments in a home are made over time, affecting the relative marital and nonmarital investments, the simple approach has-to put it simplyproven to be fundamentally unfair. ${ }^{140}$ As a result, it should only be used when the spouse who holds the separate interest in the home chooses not to present competent data on this point. The law should take account of

I36 Without exploring how it might practically (or why it must) be done, Brett Turner concludes that any approach to dividing the equity in hybrid-property homes that requires repeated calculation "raises difficult questions of mathematics that would pose an immense burden on the classification process." Turner, supra note 38 , at 902 . Admittedly, Turner's article was written prior to the development of online databases and user-friendly consumer software for such purposes. However, in his more recent writings he continues to reject any "periodic apportionment" of gains without examining the technology now available for its use or how it might feasibly be done. See, e.g., Turner, Equitable Distribution, supra note 34, § 5:25 (arguing that the level of calculation required to periodically apportion gain is "substantial").

I37 See, e.g., Amortization Schedule Calculator, Bankrate.com, http://www.bankrate.com/ calculators/mortgages/amortization-calculator.aspx (last visited Mar. 4, 20I2) (providing a free user-friendly amortization schedule calculator).

I 38 For example, the table in Appendix A was created in a few hours using Microsoft Excel.

I39 As discussed supra Part II.A, this is already the case with respect to the allocation of value of hybrid-property defined-contribution accounts between the separate and marital estates on divorce.

I40 In a similar critique, William Reppy has asserted that formulas that do not periodically apportion appreciation "seek[] simplicity frequently at the expense of serious unfairness.” Reppy, supra note i 8 , at 80. 
the new opportunities for enhanced accuracy that modern technologies, such as computer software, provide. One such opportunity is to make use of the once-daunting, but now entirely-manageable, relative-interest approach to valuing the interests in hybrid-property homes.

\section{Applying the Approach in a Declining Market}

Historically, houses have increased in value through time. ${ }^{141}$ As a result, both the example of Harry and Sally's home and the reported cases focus on the allocation of appreciation. However, since 2006, the U.S. housing market has experienced a net loss in value, ${ }^{142}$ so that courts at times must decide instead how to allocate depreciation in hybrid-property homes between the separate and marital estates. The relative-interest approach applies in the same way to losses in value as it does to gains: periodic losses should be allocated between the estates in proportion to the then-existing investments in the home just as periodic gains are allocated.

The operative principle is that, as long as each estate has a net positive balance to its interest, any losses during a given time period simply decrease the estate's cumulative interest. In other words, if an estate's contributions, increased by any appreciation allocated to that estate, are greater than the losses allocated to it, there is no change in the application of the relative-interest approach. Any losses allocated to that estate simply result in a lower equity allocation upon divorce than if the losses had not occurred, just as they would reduce the balance in an investment account.

In most cases this principle will cause the relative-interest approach to work no differently than if a steady pattern of appreciation had occurred. In the hypothetical concerning Harry and Sally, for example, depreciation would be allocated at a higher rate to the marital estate in the later years of the marriage than in the earlier years, precisely because the marital estate's allocation percentage increased through time due to the stream of marital contributions.

Mortgage financing, however, introduces a problem not present in retirement or most other investment accounts; the home's equity may be negative at the dissolution date. A home's equity can be negative in its entirety. In this case, the amount owed on the mortgage is more than the home's value-the mortgage is "underwater." Alternatively, a single estate's interest may be negative under the relative-interest approach: the

I4I See Frank E. Nothaft, The Contribution of Home Value Appreciation to US Economic Growth, 22 URb. PoL'Y \& Res. 23, 24-26 (2004) (explaining that home values have grown at an average annualized rate of six percent since 1970).

I42 See Stan Humphries, No Respite From Housing Recession in First Quarter, Zillow Real Est. Res. Blog (May 8, 20 I I), http://www.zillow.com/blog/research/20 I I/05/o8/no-respitefrom-housing-recession-in-first-quarter (charting rise and fall in home values from 1997 to $20 \mathrm{I}$, and showing decline in values since 2006). 
home equity is sufficient to cover the mortgage balance, but one estate's interest has been reduced below zero through periodic allocations of loss. How should each type of shortfall be handled?

In general, a home purchaser expects that only the amount he or she has invested in the house is potentially subject to loss if the market declines. This is because in many instances a lender cannot come after a borrower for a deficiency, either by law ${ }^{143}$ or in practice. ${ }^{144}$ Moreover, because homes constitute a high percentage of a typical family's wealth, ${ }^{145}$ in many instances outside assets are not available for a creditor to claim when a home loses value precipitously. ${ }^{146}$

To match these expectations, when only one estate's interest is negative, the estate should not be required to contribute additional assets to compensate for the shortfall. Instead, its loss should be capped at its investment, with the entire available equity being allocated to the other estate. Thus, if the value of Harry and Sally's house fell precipitously so that Harry's entire separate interest became negative but the home's equity remained positive due to the marital estate's later contributions, Harry's separate interest in the home should simply terminate, with the existing equity classified as marital property.

When the mortgage is underwater in its entirety, though, a different approach must be taken. In this case, the investments by both estates have been exposed to losses that exceed the amount of the estates' collective contributions, so that the expectations of all parties have been disrupted. In these circumstances, the unsecured portion of the debt should be allocated between the estates in proportion to their interests in the property.

I 43 Mortgages may, by law, be recourse or non-recourse. See Andra C. Ghent \& Marianna Kudlyak, Recourse and Residential Mortgage Default: Evidence from U.S. States 32 (Fed. Reserve Bank of Richmond, Working Paper No. 09-IoR, 20 I I), available at http://ssrn.com/ abstract $=\mathbf{I} 432437$ (listing Alaska, Arizona, California, Iowa, Minnesota, Montana, North Carolina, North Dakota, Oregon, Washington, and Wisconsin as non-recourse jurisdictions). In non-recourse jurisdictions, the loan is secured only by the value of the home mortgaged. This means that a lender may not come after a borrower for any deficiency. Cf. id. at 2 ("We also find that allowing the lender recourse increases the likelihood that default occurs by a more lender-friendly method .... This result is likely because lenders in recourse states have better bargaining positions.").

I44 This is because of the difficulty in most jurisdictions of obtaining a deficiency judgment. See Grant S. Nelson, Confronting the Mortgage Meltdown: A Brief for the Federalization of State Mortgage Foreclosure Law, 37 PePP. L. Rev. 583, 589-90 (2010).

I45 See Bucks et. al., supra note 3.

I46 See John Leland, Facing Default, Some Walk Out on New Homes, N.Y. Times, Feb. 29, 2008, http://www.nytimes.com/2008/02/29/us/29walks.html?oref=slogin\&pagewanted=print \&oref=slogin (noting the relative scarcity of non-housing wealth, which is one reason why few people, in practice, are held liable for shortfalls in recourse mortgages). But see Ghent \& Kudlyak, supra note I43, at I (arguing that in some cases lenders may collect the deficiency and that the threat of deficiency changes buyer behavior, if not actual default rates). 
It is important to recognize that the difficulties with underwater mortgages are not unique to the relative-interest approach. Under any allocation method, decline in a hybrid-property home's value-or the unwise payment of a too-generous initial purchase price-may generate losses that must be allocated between the separate and marital estates. This concern is not really about the relative-interest approach, but is instead a concern about equity allocations more generally. Instead, the relative-interest approach substantially improves the economic soundness, and ultimate fairness, of the equity allocations courts must already make.

\section{BROAdER IMPLications}

Analysis of current formulas used to allocate the value of hybrid-property homes between the separate and marital estates reveal a disjuncture between what the law says it is doing-providing a proportionate and fair return on each estate's investment-and what it is really doing-systematically classifying a disproportionate portion of available wealth as marital property. As a result, courts transfer substantial amounts of wealth from separate estates to marital estates without acknowledging that this is what they are doing.

Perhaps these transfers of wealth are the result of a judicial preference in favor of adding assets to the marital "pot" that courts are free to equitably distribute while still formally recognizing the existence of separate property. Alternatively, they may be relics of a time when courts concluded that the cost of the data and technology needed for sound allocation was unreasonably high. Finally, they may result from nothing more than a visceral dislike of numerical complexity in the law. Regardless, the problem created by the current approaches requires close examination, so that the legal rhetoric and legal reality are brought into alignment to provide more accurate, more transparent, and more just outcomes for litigants.

\section{A. Transparency in Wealth Transfers}

The disjuncture between the legal rhetoric and legal reality in the division of equity in hybrid-property homes may be a disguised way for courts to increase their flexibility in distributing assets between divorcing spouses. While common law jurisdictions historically awarded property on divorce to the spouse in whose name it was titled regardless of when it was acquired ${ }^{147}$ they have increasingly viewed the marital unit as a partnership,

i 47 See John DeWitt Gregory, The Law of Equitable Distribution i-i (i989) (explaining that under the traditional common law system "a spouse was entitled to receive the property held in his name"); Rosenbury, supra note 33, at I235-38 (providing an overview of traditional spousal property rights during and at the end of marriage in common law jurisdictions). 
with all marital assets being shared between spouses. ${ }^{148}$ Some commentators have argued that even some portion of separate property should be included in the equitable distribution pot, on the theory that most individuals enter marriage with the expectation that their economic fortunes will be merged with those of their spouse. ${ }^{149}$

Even so, assets classified as separate property are, in general, allocated upon divorce to the spouse who acquired them. ${ }^{150}$ On the other hand, assets classified as marital property are generally divided between the spouses based on equitable factors, including the respective separate property holdings of each spouse. ${ }^{151}$ As a result, by increasing the portion of a home's net equity that is classified as marital property, a court increases its flexibility to make decisions about the ultimate disposition of the assets. Perhaps courts are attracted to this increase in flexibility; perhaps courts favor allocation formulas that shift property into the marital estate because they increase the assets over which the court retains discretion and, thus, increase power.

This increase in power may, in turn, allow courts to address the disproportionately negative economic effect divorce has on women when compared to men: ${ }^{152}$ if men hold more wealth as separate property than do women, and current approaches to dividing the equity in hybrid-property homes shift wealth from the separate estate to the marital estate, then current formulas may make a greater portion of wealth available for equitable distribution to women than would the relative-interest approach. The difficulty with this line of reasoning is that it rests on a fundamentally unsupported assumption. For at least the last forty years, more unmarried

I48 See, e.g., David R. Knauss, Comment, What Part of Yours is Mine?: The Creation of Marital Property Ownership Interest by Improving Nonmarital Property Under Wisconsin's Marital Property Law, 2005 WIS. L. Rev. 855, 855 (2005) ("Marriage is a partnership. Every partnership experiences gains and losses. These gains and losses are shared among the partners, typically in proportion to each partner's capital contribution."); Motro, supra note 29, at I623 ("Most jurisdictions' current family law systems embody the principle that marriage turns separate individuals into economic partners.").

I 49 See, e.g., Law of Family Dissolution, supra note $20, \S 4.12 \mathrm{cmt}$. a (providing for an increasing share of separate property to be recharacterized as marital based on the length of the marriage); Motro, supra note 29, at I64I (suggesting that an increasing percent of separate property, based on the marriage duration and expected remaining lifespan of owner-spouse, should be available for equitable distribution).

I50 See supra note 32 and accompanying text.

I5 I See supra note 33 and accompanying text.

I 52 See, e.g., Suzanne M. Bianchi et al., The Gender Gap in the Economic Well-Being of Nonresident Fathers and Custodial Mothers, 36 DEMOGRAPHY I95, I97-99 ( I999) (estimating that economic well-being, as defined by income relative to needs, declines for women by thirty-six percent and rises for men by twenty-eight percent among divorcing couples with children); Patricia A. McManus \& Thomas A. DiPrete, Losers and Winners: The Financial Consequences of Separation and Divorcefor Men, 66 Aм. Soc. Rev. 246, 246 (200I) ("[T] here is overwhelming evidence supporting the view that women's standard of living declines—often precipitously—following separation or divorce...."). 
women than unmarried men have purchased houses in the U.S. ${ }^{153}$ While it is not clear whether these homes were then brought into a marriage so as to become hybrid property, this clear trend at least raises a question about whether the effect of formulas that shift home wealth from the separate to the marital estate in fact favor women. The hidden transfers of the wealth caused by current allocation formulas may in fact be transferring wealth away from women's separate estates.

Regardless, opaque transfers of wealth by courts to increase their discretion in distributing assets make little sense. A more effective-and more forthright - approach would be simply to give judges greater discretion in dividing up separate property upon divorce. ${ }^{154}$ But even if there is something to this possible justification for the current approach, courts should openly acknowledge what they are doing. To the extent that courts are hiding such transfers of wealth behind legal rhetoric proclaiming that their methods of equity allocation in hybrid-property homes are proportionate and fair, they are undermining their own legitimacy through the use of deception. A divorcing couple's financial situation should be determined under sensible principles of law, with any transfers of wealth occurring in the plain view of the individuals involved.

\section{B. Obsolescence Due to Technological Advances}

Alternatively, current approaches to dividing the equity in hybrid-property homes may be a product of an earlier time period, when the available technology was such that the greater accuracy of the relative-interest approach was outweighed by its higher cost.

When current formulas were being developed twenty to thirty years ago, ${ }^{155}$ home computer use was uncommon. ${ }^{156}$ The mechanics of the rela-

I53 See, e.g., Nat'l Ass'N of Realtors, supra note 8, at 9 (showing that approximately twice as many unmarried women as unmarried men purchased homes in the U.S. in 2010); Donald R. Haurin \& Duewa A. Kamara, The Homeownership Decisions of Female-Headed Households, 2 J. Housing Econ. 293, 295 ( I992) (showing rates of homeownership for never-married men of $0.9 \%$ and $22.2 \%$ in I $97 \mathrm{I}$ and I $98 \mathrm{I}$, respectively, as compared to rates of II.2\% and $31.1 \%$ in 1972 and 1982 for never-married women).

I54 In fact, this is what recent reform proposals have suggested. See supra notes $28-29$ and accompanying text (summarizing recent proposals to transmute separate property into marital property over the course of the marriage).

I55 Brandenburg and Schmitz were decided in I98I, Thomas in I989, and Hoffman in 1992. See Thomas v. Thomas, 377 S.E.2d 666, 667-70 (Ga. I989); Brandenburg v. Brandenburg, 6 77 S.W.2d 87I, 872 (Ky. Ct. App. I98I); Hoffman v. Hoffman, 6 I 4 A.2d 988, 995-98 (Md. Ct. Spec. App. I992); Schmitz v. Schmitz, 309 N.W.2d 748, 750 (Minn. I98I).

I56 Ludwig Braun, The Computer in the Home-Boon or Boondoggle?, 2 Educ. \& ComputING I 45, I 45 ( I986) (explaining that only fourteen million computers were in American homes in 1986 and that practical applications for the devices were just beginning to be explored). According to the U.S. Census Bureau, home computer use grew from $8.2 \%$ of households in I984 to 6 I.8\% in 2003, with $68.7 \%$ of U.S. households online in 2009. See Computer and Internet 
tive-interest approach, which requires tracking each contribution to a home's value and recalculating the allocation percentages manually on a monthly basis, would have required substantial investments of time and money on the part of divorcing spouses. The necessary home valuation data was not readily available either: the FHFA, for example, only includes data from 1991 through the present in its House Price Calculator. ${ }^{157}$

Today, however, user-friendly software allows the quick, easy, and cheap calculation (and recalculation) of each estate's allocation percentages. The availability of searchable online price indexes simplifies data collection. Assuming the relative-interest approach is adopted, specialized software for tracking and calculating each estate's interest, linked to indexes with monthly change-of-value information, would surely be developed. Alternatively, where the contribution patterns are more complex, actuaries or accountants could be employed for this task. ${ }^{158}$

While current formulas might have been appropriate for the time period in which they were developed, they no longer provide an appropriate way to divide the equity in a hybrid-property home. Technological advances and greater data availability require that states update their approaches by including the timing of each estate's investments and their associated returns in allocation calculations.

\section{Overcoming Innumeracy in the Law}

The misalignment of legal rhetoric and legal reality may be a product of the law's distaste for-and discomfort with-all but simple calculations. Both popular authors ${ }^{159}$ and academics ${ }^{160}$ have examined the problem of innumeracy in American society. Omri Ben-Shahar and Carl E. Schneider re-

Use, U.S. Census Bureau (Feb. 2010), http://www.census.gov/hhes/computer.

I57 See HPI Calculator, supra note 68. Data including home refinancings, often considered less reliable than purchase-only data, are available for download from the FHFA from I 975 through the present. FHFA Help Desk E-mail, supra note 95.

I 58 For example, in instances where a home is refinanced, an expert accustomed to calculating the interests may be helpful. This is the approach generally taken with respect to dividing the value of hybrid-property retirement accounts.

i59 See, e.g., John Allen Paulos, Innumeracy: Mathematical Illiteracy and Its ConSEQUENCES 3 ( I988) ("Innumeracy, an inability to deal comfortably with the fundamental notions of number and chance, plagues far too many otherwise knowledgeable citizens.").

I6o See generally Christopher C. Fennell \& Lee Anne Fennell, Fear and Greed in Tax Policy: A Qualitative Research Agenda, I3 WASH. U. J.L. \& PoL'Y 75, 75-77 (2003) (discussing innumeracy and taxpayer filing decisions); Joseph H. King, Jr., Pain and Suffering, Noneconomic Damages, and the Goals of Tort Law, 57 SMU L. Rev. I63, I65-66 (2004) (discussing innumeracy in the context of jury awards for pain and suffering); Bailey Kuklin, Probability Misestimates in Medical Care, 59 Ark. L. Rev. 527, 527 (2006) (discussing innumeracy in medical-decision-making); Ann Morales Olazábal \& Howard Marmorstein, Structured Products for the Retail Market: The Regulatory Implications of Investor Innumeracy and Consumer Information Processing, 52 ARIz. L. Rev. 623, 624-28 (2010) (discussing innumeracy evidenced by investors). 
port that American "[r]ates of innumeracy are worse than rates of illiteracy," citing research showing that, at least in one test, forty percent of individuals in a group that was predominantly college-educated was unable to "solve a basic probability problem or convert a percentage to a proportion." 161 For example, financial innumeracy, in which people avoid financial decision-making or underutilize available financial information, is pervasive: researchers have found that American workers avoid even thinking about saving for retirement or making investment decisions with respect to the assets they hold in their retirement plans. ${ }^{162}$ Some legal academics have turned the analytical lens inward, examining innumeracy on the part of lawyers and judges. ${ }^{163}$

Current formulas for dividing the equity in hybrid-property homes upon divorce may exemplify the troubling presence of innumeracy in the law. To the extent courts believe they are allocating a proportionate and fair return on each of the separate and marital estates' investments through the use of the current allocation formulas, they are simply - and deeply-mistaken about the interaction of time and returns on investments. Because the costs of overcoming innumeracy in this context are low while the ben-

I6I Omri Ben-Shahar \& Carl E. Schneider, The Failure of Mandated Disclosure, I59 U. PA. L. Rev. 647, 7I 2 (201 I) (citation omitted). In many instances, dyscalculia-the numerical equivalent of dyslexia-may underlie this discomfort. Dyscalculia has been defined more rigorously as "a severe disability in learning arithmetic" and is not associated with low mental functioning generally. Brian Butterworth, et al., Dyscalculia: From Brain to Education, Science, May 27, 20I I, at 1049, I049. A leading researcher in dyscalculia reports that between three and six percent of people have been estimated to have developmental dyscalculia. Anna J. Wilson, Dyscalculia Primer and Research Guide, Org. For Econ. Co-operation \& Dev., http://www.oecd. org/document/8/o,3746,en_2649_3584558I_34495560_I_I_I_I,oo.html (last visited June I4, 20II).

I62 Ben-Shahar \& Schneider, supra note I6I, at 728.

I63 Based on an analysis of the use of probabilistic statistics in paternity cases, criminal law, damages in tort cases, and securities fraud, Michael I. Meyerson and William Meyerson argue that, in many instances, "judicial mathematical illiteracy" perverts justice by overvaluing the available mathematical evidence. See Michael I. Meyerson \& William Meyerson, Significant Statistics: The Unwitting Policy Making of Mathematically Ignorant Judges, 37 Pepr. L. Rev. 77I, 77I (2010). The Meyersons note that "the apparent objectivity of mathematics often masks subjective judgments, and [judges need to] not be fooled when 'hard' numbers are really based on little more than intuition and guesswork. Numbers can communicate important information. Judges just need to make sure that they are able to comprehend what those numbers are trying to say." $I d$. at 846 (footnotes omitted). To help remedy this form of innumeracy, they suggest that judges appoint experts to properly weigh mathematical evidence. Id. at 775 .

See also Lars Noah, An Inventory of Mathematical Blunders in Applying the Loss-of-a-Chance Doctrine, 24 Rev. Litig. 369, 403-04 (2005) (concluding that routine miscalculations in lossof-a-chance claims undermine the theory's practical utility); Laurence H. Tribe, Trial by Mathematics: Precision and Ritual in the Legal Process, 84 Harv. L. Rev. I329, I330-3 I, I392-93 ( 97 I) (arguing that probabilistic proof should only be used in trials in truly extraordinary circumstances to avoid its overvaluation). 
efits of doing so are high, reform of the methods for apportioning equity in hybrid-property homes is appropriate. ${ }^{164}$

In the final analysis, current approaches to dividing the equity in hybrid-property homes sacrifice accuracy, transparency, and fairness for mathematical simplicity. As a result, courts make sweeping and secret transfers of wealth under the guise of providing a proportionate and fair return on investment. A better approach is for courts and legislators to align legal rhetoric and legal reality by adopting the relative-interest approach so that each estate receives the benefit - and bears the burden - of the investments it has made. State authorities should also develop tools to aid the making of the necessary calculations, such as spreadsheet models into which data can be entered or software linked to the appropriate data sources, for the consistent and appropriate application of this economically sound approach.

\section{Conclusion}

The formulas currently used to divide the equity in a hybrid-property home between the separate and marital estates upon divorce do not make economic sense. While professing to afford each estate a proportionate and fair return on its investment in the property, courts are opaquely transferring substantial amounts of wealth from separate estates to marital estates. By considering the times at which each estate's contributions to the home's value were made, and allocating appreciation between the estates in proportion to their relative interests each time an additional contribution is made, a home's equity can be proportionately and fairly allocated upon divorce.

Current allocation formulas create a disjuncture between legal rhetoric and legal reality. To the extent this misalignment results from judicial efforts to obscure transfers of wealth from the separate to the marital estate, there should be an open and honest discussion about the transfer. On the other hand, to the extent the mismatch is the result of former technological limitations or legal innumeracy, the current formulas should be reexamined and replaced with a more rigorous methodology. Regardless of a particular court's reason or combination of reasons for maintaining this disparity, courts should reject current approaches to allocating the equity in hybridproperty homes and embrace the relative-interest approach.

I64 It may be in some cases that accountants or other mathematically competent professionals will need to be hired to assist in the allocation process where they currently would not be necessary. 

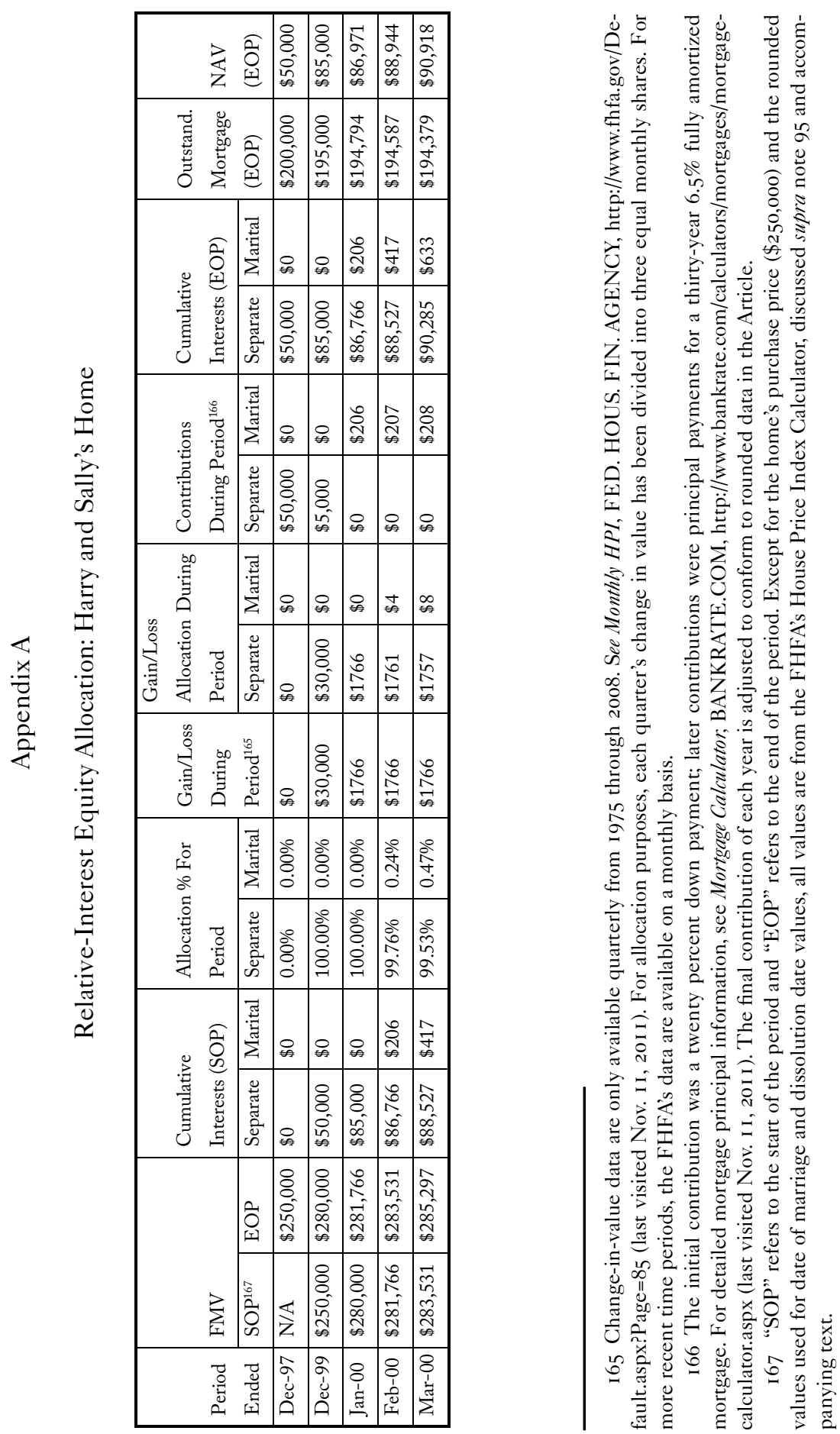


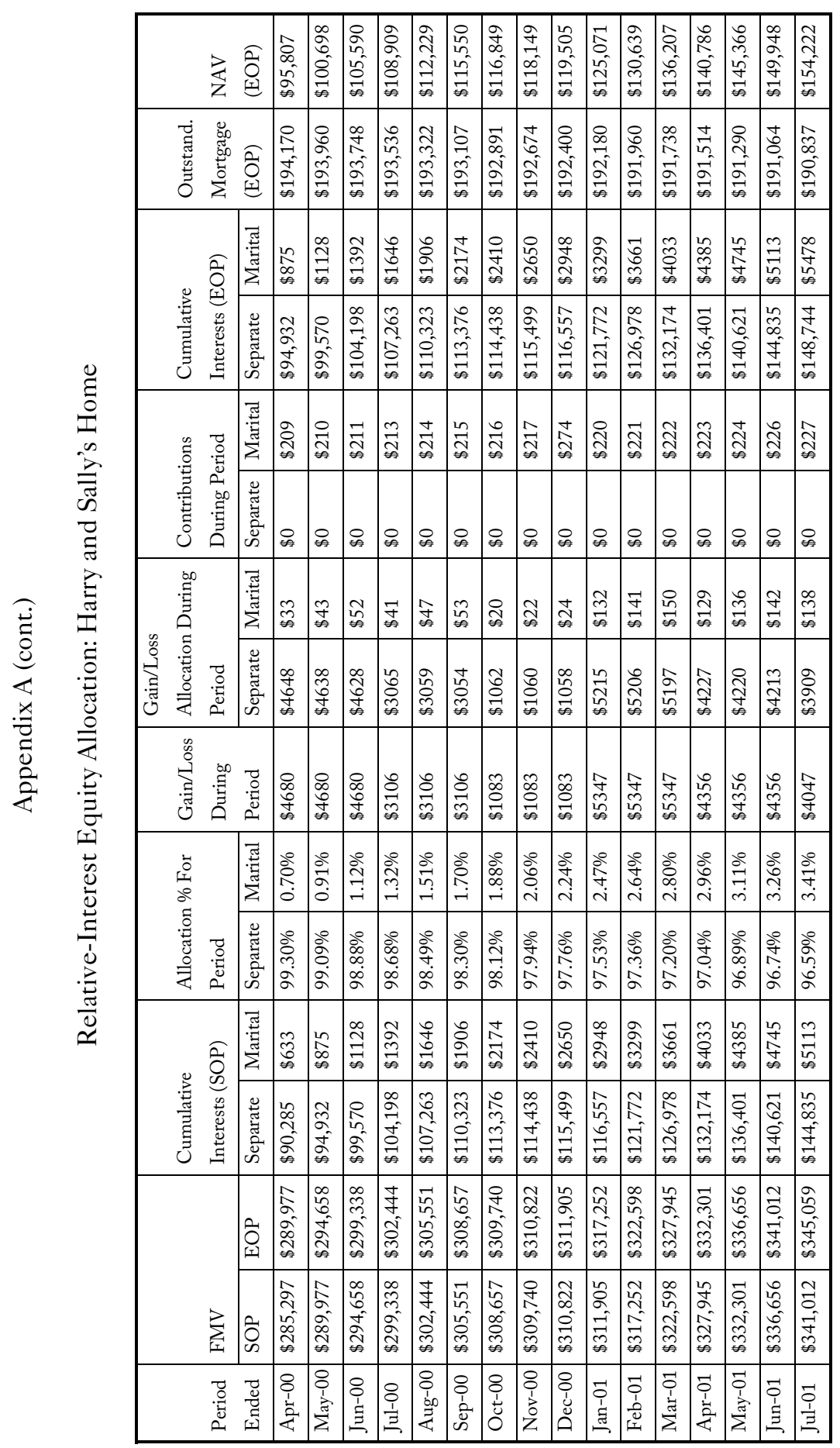




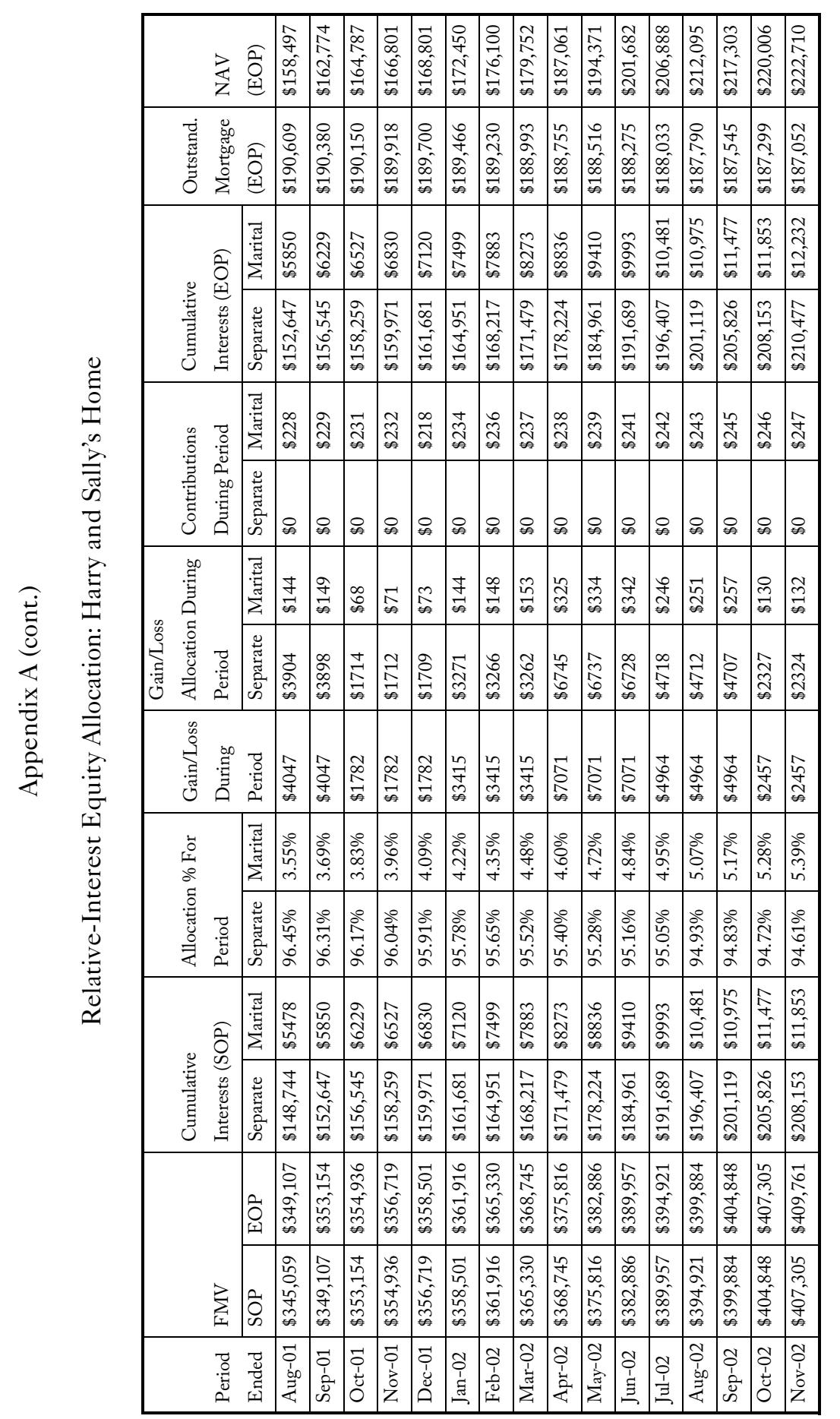




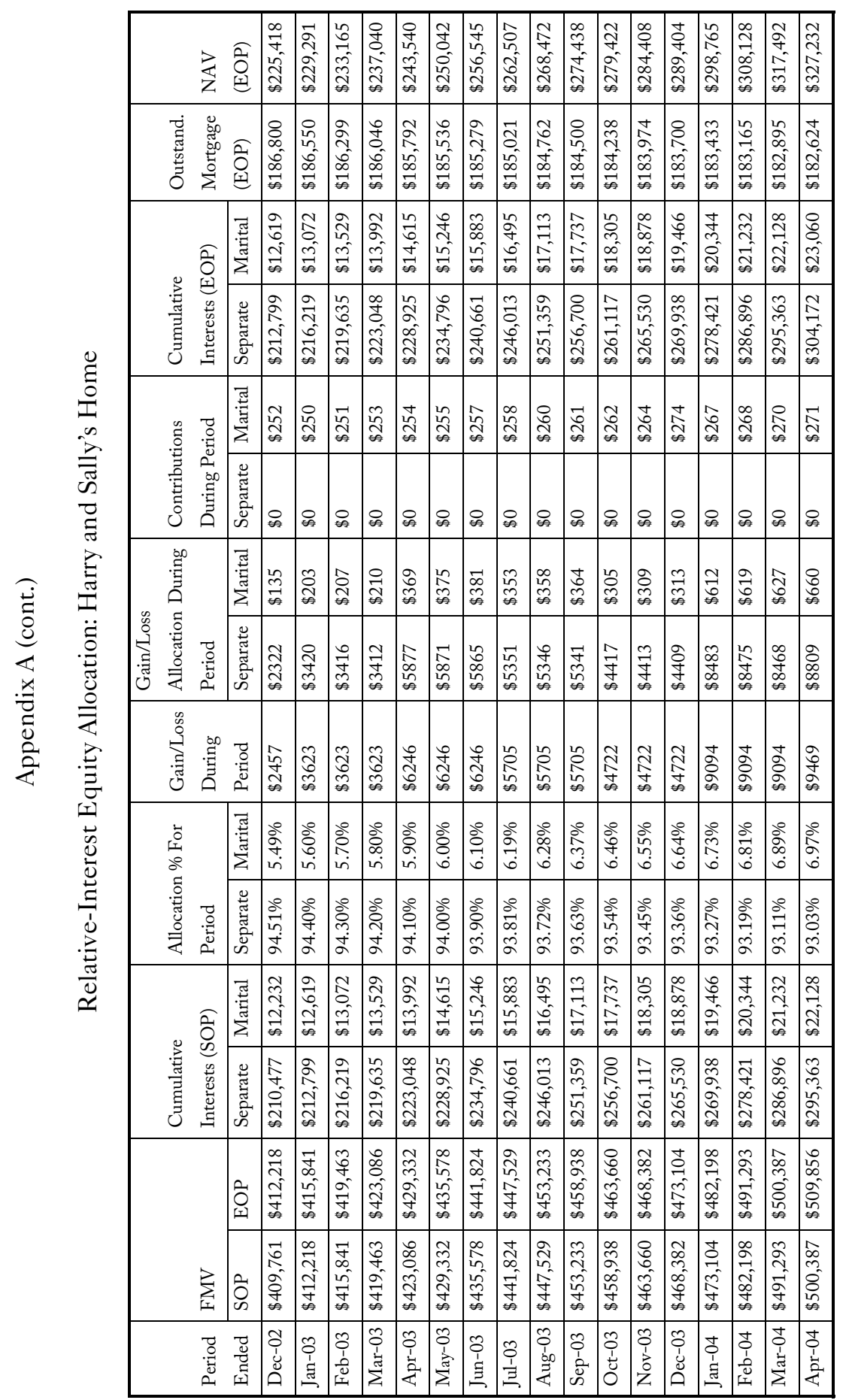




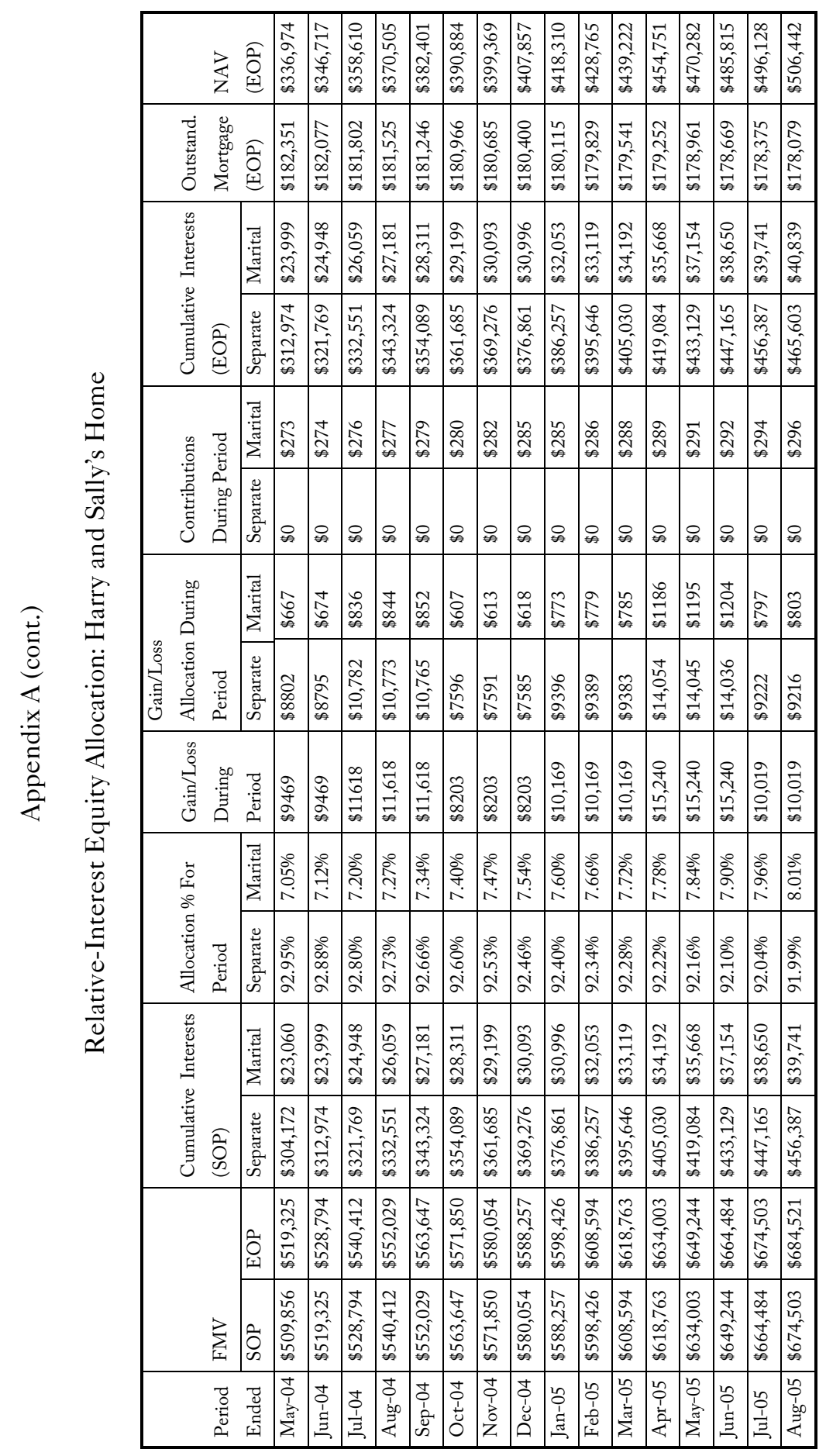




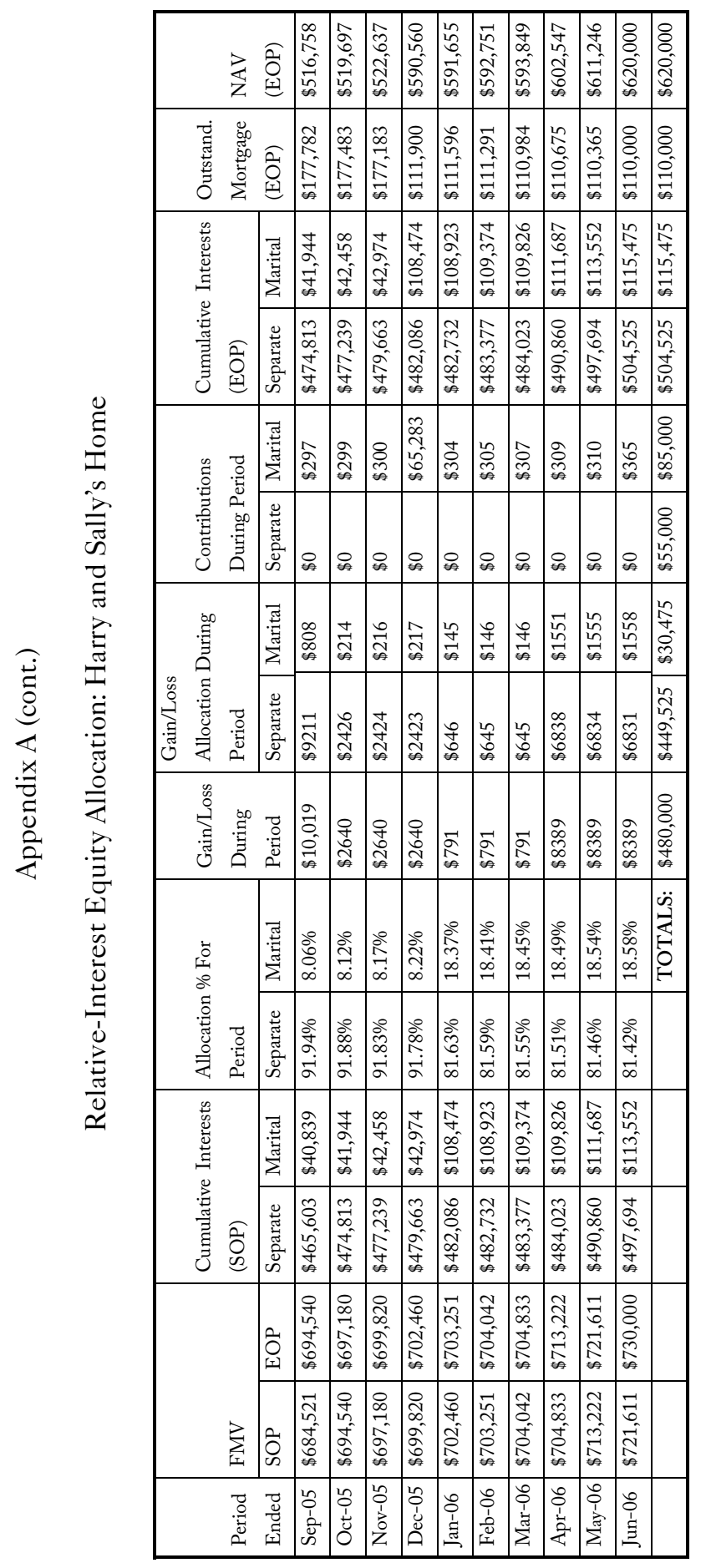




\section{Appendix B}

Marital Estate Equity Allocation If Afforded Same Annual Rate of Return (21.934\%) as Separate Estate Under Brandenburg Formula

\section{(Contributions at End of Period)}

\begin{tabular}{|c|c|c|c|c|c|c|c|}
\hline \multirow[b]{2}{*}{ Period } & \multicolumn{3}{|c|}{ Separate Interest } & \multicolumn{4}{|c|}{ Marital Interest } \\
\hline & $\begin{array}{l}\text { Value } \\
\text { (Start of } \\
\text { Period) }{ }^{168}\end{array}$ & $\begin{array}{l}21.934 \% \\
\text { Return }\end{array}$ & $\begin{array}{l}\text { Value (End } \\
\text { of Period) }\end{array}$ & $\begin{array}{l}\text { Value } \\
\text { (Start of } \\
\text { Period) }{ }^{169}\end{array}$ & $\begin{array}{l}21.934 \% \\
\text { Return }\end{array}$ & \multicolumn{2}{|l|}{$\begin{array}{l}\text { Value } \\
\text { (End of Period) }\end{array}$} \\
\hline Dec. 1999- & \multirow{2}{*}{$\$ 85,000$} & \multirow{2}{*}{$\$ 18,644$} & \multirow{2}{*}{$\$ 103,644$} & \multirow{2}{*}{ \$o } & \multirow{2}{*}{$\$ 0$} & Cumulative & $\$ 0$ \\
\hline Dec. 2000 & & & & & & Contributions & $\$ 2600$ \\
\hline Dec. 2000- & \multirow{2}{*}{$\$ 103,644$} & \multirow{2}{*}{$\$ 22,733$} & \multirow{2}{*}{$\$ 126,377$} & \multirow{2}{*}{$\$ 2600$} & \multirow{2}{*}{$\$ 570$} & Cumulative & $\$ 3170$ \\
\hline Dec. 2001 & & & & & & Contributions & $\$ 2700$ \\
\hline Dec. 2001- & \multirow{2}{*}{$\$ 126,377$} & \multirow{2}{*}{$\$ 27,720$} & \multirow{2}{*}{$\$ 154,097$} & \multirow{2}{*}{$\$ 5870$} & \multirow{2}{*}{$\$ 1288$} & \begin{tabular}{|l|} 
Cumulative \\
\end{tabular} & $\$ 7158$ \\
\hline Dec. 2002 & & & & & & Contributions & $\$ 2900$ \\
\hline Dec. 2002- & \multirow{2}{*}{$\$ 154,097$} & \multirow{2}{*}{$\$ 33,800$} & \multirow{2}{*}{$\$ 187,896$} & \multirow{2}{*}{$\$ 10,058$} & \multirow{2}{*}{$\$ 2206$} & Cumulative & $\$ 12,264$ \\
\hline Dec. 2003 & & & & & & Contributions & $\$ 3100$ \\
\hline Dec. 2003- & \multirow{2}{*}{$\$ 187,896$} & \multirow{2}{*}{$\$ 41,213$} & \multirow{2}{*}{$\$ 229,109$} & \multirow{2}{*}{$\$ 15,364$} & \multirow{2}{*}{$\$ 3370$} & Cumulative & $\$ 18,734$ \\
\hline Dec. 2004 & & & & & & Contributions & $\$ 3300$ \\
\hline Dec. 2004- & \multirow{2}{*}{$\$ 229,109$} & \multirow{2}{*}{$\$ 50,253$} & \multirow{2}{*}{$\$ 279,362$} & \multirow{2}{*}{$\$ 22,034$} & \multirow{2}{*}{$\$ 2416$} & Cumulative & $\$ 24,450$ \\
\hline Dec. 2005 & & & & & & Contributions & $\$ 68,500$ \\
\hline Dec. 2005- & \multirow{2}{*}{$\$ 279,362$} & \multirow{2}{*}{$\$ 30,638^{170}$} & 831000 & 502050 & ه10 1 $14^{171}$ & Cumulative & $\$ 103,144$ \\
\hline June 2006 & & & & 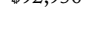 & ד ד & Contributions & $\$ 1900$ \\
\hline June 2006 & $\$ 31000$ & N/A & V/A & $\$ 10504$ & $N / 4$ & Cumulative & N/A \\
\hline & 年 & $N / \Lambda$ & $1 N / \pi$ & 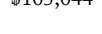 & $N / A$ & Contributions & N/A \\
\hline
\end{tabular}

I68 The starting value for the separate interest was Harry's equity in the home at the time of marriage. No further nonmarital contributions were assumed.

I69 All contributions are the rounded annual principal payments on a \$200,000 mortgage, assuming a $6.5 \%$ interest rate and thirty-year term.

I 70 The return for 2006 is only calculated for the trailing six-month period until the divorce in June.

I 7 I Includes both the unscheduled $\$ 65,000$ payment and $\$$ I 900 (rounded) in scheduled principal payments for the remaining six-month term of the marriage. 


\section{Appendix C}

Annual Rate of Return (91.9214\%) for Marital Interest Needed to Produce Brandenburg Result

(Contributions at End of Period) $)^{172}$

\begin{tabular}{|c|c|c|c|c|}
\hline \multirow[b]{2}{*}{ Period } & \multicolumn{4}{|c|}{ Marital Interest } \\
\hline & $\begin{array}{l}\text { Value (Start } \\
\text { of Period) }\end{array}$ & $\begin{array}{l}91.9214 \% \\
\text { Return }\end{array}$ & \multicolumn{2}{|l|}{$\begin{array}{l}\text { Value } \\
\text { (End of Period) }\end{array}$} \\
\hline Dec. 1999- & \multirow{2}{*}{$\$ 0$} & \multirow{2}{*}{$\$ 0$} & Cumulative & $\$ 0$ \\
\hline Dec. 2000 & & & Contributions & $\$ 2600$ \\
\hline Dec. 2000- & \multirow{2}{*}{$\$ 2600$} & \multirow{2}{*}{$\$ 2390$} & Cumulative & $\$ 4990$ \\
\hline Dec. 2001 & & & Contributions & $\$ 2700$ \\
\hline Dec. 2001- & \multirow{2}{*}{$\$ 7690$} & \multirow{2}{*}{$\$ 7069$} & Cumulative & $\$ 14,759$ \\
\hline Dec. 2002 & & & Contributions & $\$ 2900$ \\
\hline Dec. 2002- & \multirow{2}{*}{$\$ 17,659$} & \multirow{2}{*}{$\$ 16,232$} & Cumulative & $\$ 33,891$ \\
\hline Dec. 2003 & & & Contributions & $\$ 3100$ \\
\hline Dec. 2003- & \multirow{2}{*}{$\$ 36,991$} & \multirow{2}{*}{$\$ 34,002$} & Cumulative & $\$ 70,993$ \\
\hline Dec. 2004 & & & Contributions & $\$ 3300$ \\
\hline Dec. 2004- & \multirow{2}{*}{$\$ 74,293$} & \multirow{2}{*}{$\$ 68,291$} & Cumulative & $\$ 142,585$ \\
\hline Dec. 2005 & & & Contributions & $\$ 68,500$ \\
\hline Dec. 2005- & \multirow{2}{*}{$\$ 211,085$} & \multirow{2}{*}{$\$ 97,016^{173}$} & Cumulative & $\$ 308,100$ \\
\hline June 2006 & & & Contributions & $\$ 1900$ \\
\hline \multirow[t]{2}{*}{ June 2006} & \multirow{2}{*}{$\$ 310,000$} & \multirow{2}{*}{ N/A } & Cumulative & N/A \\
\hline & & & Contributions & N/A \\
\hline
\end{tabular}

I 72 The rate of return is calculated as though each contribution were made at the end of each period.

I 73 The return for 2006 is only calculated for the trailing six-month period until the divorce in June. 


\section{Appendix D}

Absolute (\$) and Relative (\%) Contributions

\begin{tabular}{|c|c|c|c|c|c|c|}
\hline \multirow[b]{2}{*}{ Period } & \multicolumn{2}{|c|}{ Start of Period } & \multicolumn{2}{|c|}{ During Period } & \multicolumn{2}{|c|}{ End of Period } \\
\hline & $\begin{array}{l}\text { Separate } \\
\text { Estate }\end{array}$ & $\begin{array}{l}\text { Marital } \\
\text { Estate }\end{array}$ & $\begin{array}{l}\text { Separate } \\
\text { Estate }\end{array}$ & $\begin{array}{l}\text { Marital } \\
\text { Estate }\end{array}$ & $\begin{array}{l}\text { Separate } \\
\text { Estate }\end{array}$ & $\begin{array}{l}\text { Marital } \\
\text { Estate }\end{array}$ \\
\hline Dec. 1999- & $\$ 85,000$ & $\$ 0$ & \multirow[t]{2}{*}{$\$ 0$} & \multirow[t]{2}{*}{$\$ 2600$} & $\$ 85,000$ & $\$ 2600$ \\
\hline Dec. 2000 & $100 \%$ & $0 \%$ & & & $97 \%$ & $3.0 \%$ \\
\hline Dec. 2000- & $\$ 85,000$ & $\$ 2600$ & \multirow[t]{2}{*}{$\$ 0$} & \multirow[t]{2}{*}{$\$ 2700$} & $\$ 85,000$ & $\$ 5300$ \\
\hline Dec. 2001 & $97 \%$ & $3.0 \%$ & & & $94.1 \%$ & $5.9 \%$ \\
\hline Dec. 2001- & $\$ 85,000$ & $\$ 5300$ & \multirow[t]{2}{*}{$\$ 0$} & \multirow[t]{2}{*}{$\$ 2900$} & $\$ 85,000$ & $\$ 8200$ \\
\hline Dec. 2002 & $94.1 \%$ & $5.9 \%$ & & & $91.2 \%$ & $8.8 \%$ \\
\hline Dec. 2002- & $\$ 85,000$ & $\$ 8200$ & \multirow[t]{2}{*}{$\$ 0$} & \multirow[t]{2}{*}{$\$ 3100$} & $\$ 85,000$ & $\$ 11,300$ \\
\hline Dec. 2003 & $91.2 \%$ & $8.8 \%$ & & & $88.3 \%$ & $11.7 \%$ \\
\hline Dec. 2003- & $\$ 85,000$ & $\$ 11,300$ & \multirow[t]{2}{*}{$\$ 0$} & \multirow[t]{2}{*}{$\$ 3300$} & $\$ 85,000$ & $\$ 14,600$ \\
\hline Dec. 2004 & $88.3 \%$ & $11.7 \%$ & & & $85.3 \%$ & $14.7 \%$ \\
\hline Dec. 2004- & $\$ 85,000$ & $\$ 14,600$ & \multirow[t]{2}{*}{$\$ 0$} & \multirow[t]{2}{*}{$\$ 3500$} & $\$ 85,000$ & $\$ 18,100$ \\
\hline Dec. 2005 & $85.3 \%$ & $14.7 \%$ & & & $82.4 \%$ & $17.6 \%$ \\
\hline Dec. 2005- & $\$ 85,000$ & $\$ 18,100$ & \multirow[t]{2}{*}{$\$ 0$} & \multirow[t]{2}{*}{$\$ 66,900$} & $\$ 85,000$ & $\$ 85,000$ \\
\hline June 2006 & $82.4 \%$ & $17.6 \%$ & & & $50.0 \%$ & $50.0 \%$ \\
\hline \multirow[t]{2}{*}{ June 2006} & $\$ 85,000$ & $\$ 85,000$ & \multirow[t]{2}{*}{ N/A } & \multirow[t]{2}{*}{ N/A } & N/A & N/A \\
\hline & $50.0 \%$ & $50.0 \%$ & & & N/A & N/A \\
\hline
\end{tabular}



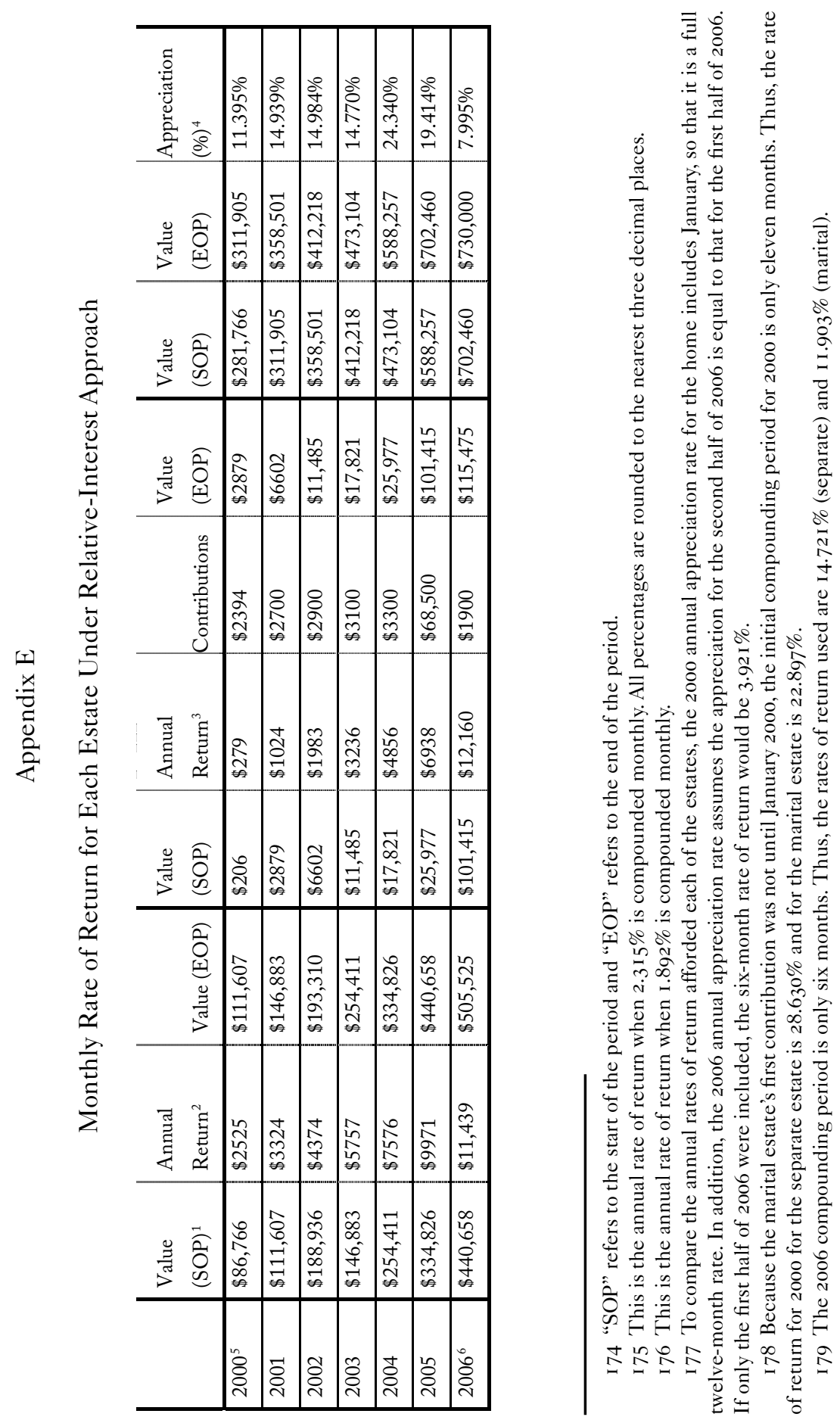